\title{
Deal Size, Acquisition Premia and Shareholder Gains
}

\author{
G. Alexandridis, K.P. Fuller, L.Terhaar and N.G. Travlos *
}

January 2011

\begin{abstract}
:
Existing literature documents that large acquisitions destroy more value for acquiring shareholders than small acquisitions and attributes this to overpayment driven by managerial incentives and/or overconfidence. Nevertheless, the less intense competition, higher value at stake, lower managerial ownership and/or sizeable complexity of post-merger integration associated with large targets can result in lower acquisition premia. We examine these contradictory predictions and document a robust negative relation between target size and the premium paid in acquisitions. We also find that, despite the payment of lower premia, acquisitions of large targets destroy more value for acquirers and result in sharper increases in their return uncertainty around the deal announcement, implying that investors perceive these deals as more uncertain projects. Acquirers of large firms continue to underperform small target acquirers in the long-run in terms of both stock market and operating performance which indicates that they fail to deliver the assumed synergies. Our evidence suggests that large deals tend to be too big to succeed, irrespective of the premium paid.
\end{abstract}

Keywords: Public acquisitions, target size, premium, acquirer returns

JEL Classification: G14, G30, G34

*Alexandridis and Terhaar are from the ICMA Centre, Henley Business School, Reading University, U.K. Fuller is from the University of Mississippi, U.S. and Travlos is from ALBA Graduate Business School, Greece. Travlos acknowledges financial support received from the Kitty Kyriacopoulos Chair in Finance. All errors are our own. 


\section{Introduction}

There is compelling empirical evidence that large acquisitions destroy more value for shareholders of acquiring companies. BusinessWeek (2002) reports that $61 \%$ of merger deals worth at least $\$ 500$ million end up costing shareholders. ${ }^{1}$ Similarly, research by Boston Consulting Group (2007) shows that "megadeals" priced at more than \$1 billion destroy nearly twice as much value relative to smaller transactions. ${ }^{2}$ Loderer and Martin (1990) argue that acquirers lose more in large deals because they pay too much. This can be the case if excessively confident managers, that overestimate their ability to extract acquisition benefits (Roll, 1986; Hayward and Habrick, 1997; Malmendier and Tate, 2008), tend to bid for larger firms. Moreover, managers may overpay for large targets because they generally provide particularly high private benefits (Morck, Shleifer and Vishny, 1990; Loderer and Martin, 1990; Grinstein and Hribar, 2004; Harford and Li, 2007).

Nevertheless, there are several reasons why acquirers would offer lower premia in large deals. High value at stake, for instance, can result in more accurate valuations or can make managers and their boards more hesitant to offer hefty premiums. ${ }^{3}$ It can also motivate acquirers to hire more reputable financial advisors that, in turn, may provide better advice or negotiate better deals. Moreover, the complexity of integrating large firms can make expected synergies from the combination more uncertain and therefore lead to lower premia. ${ }^{4}$ Competition for large targets is also less intense if there are fewer potential buyers for large firms (Gorton, Kahl and Rosen, 2009), reducing the "winner's curse" problem and leading to

\footnotetext{
1 “Mergers: Why Most Big Deals Don't Pay Off”, BusinessWeek, 14 October 2002.

2 "A Brave New World of M\&A: How to Create Value from Mergers and Acquisitions", The Boston Consulting Group, July 2007.

${ }^{3}$ Valuations for large firms can also be more accurate due to greater information availability (Atiase, 1985; Collins, Kothari and Rayburn, 1987) and more extensive analyst following that tends to reduce information asymmetry (Chang, Dasgupta and Hilary, 2006).

${ }^{4}$ Shrivastava (1986) argues that post-merger integration entails the physical, procedural, managerial and/or cultural combination of firms, which further involve the integration of organizational systems and processes, corporate cultures, performance and reward systems as well as people. Shrivastava (1986) and Hayward (2002) suggest that post-merger integration is a function of organizational size.
} 
lower acquisition premia. ${ }^{5}$ Finally, large firms tend to be subject to lower managerial ownership (Demsetz and Lehn, 1985) and thus may accept lower premia, which, in turn, leads to less gains for their shareholders (Bauguess, Moeller, Schlingemann and Zutter, 2009).

Given the conflicting predictions regarding the association between the size of M\&A deals and takeover premiums, we empirically examine its direction using a sample of 3,691 U.S. public acquisitions announced between 1990 and 2007. In addition, we further explore the relation between target firm size and gains to acquiring companies. We find that acquirers pay significantly lower premia in large deals. The mean premium paid for targets in the top size tercile (38\%) is $30 \%$ lower than the premium for targets in the bottom tercile $(54 \%)$. The negative association between target size and the offer premium persists through time, irrespective of the premium measure used and after controlling for other known determinants of takeover premia. Industry abnormal premium, a proxy for overpayment, is also inversely related with the size of the firm being acquired. Moreover, we document that short-run abnormal returns to acquiring firms decrease with the size of the target firm, which implies that investors tend to punish acquirers of large targets more, despite the lower premiums paid. ${ }^{6}$ Accordingly, we find that the combined announcement return to acquirers and targets is also negatively associated with the size of the target.

Furthermore, we document that the return uncertainty of acquiring firms increases significantly more following the announcement of large deals, suggesting that investors perceive large acquisitions as more uncertain projects. We therefore examine whether investors are merely overreacting to greater uncertainty about large deals around the announcement, ignoring the lower premia paid, by assessing the post-merger stock market

\footnotetext{
${ }^{5}$ Takeover likelihood models predict that the probability of being acquired is significantly lower for large firms (Hasbrouck, 1985; Palepu, 1986). Alexandridis, Petmezas and Travlos (2010) find a positive association between takeover competition and acquisition premiums.

${ }^{6}$ For other studies showing that large M\&A deals destroy more value for acquirers see for example, Fuller, Netter and Stegemoller (2002), Officer (2003) and Bayazitova, Kahl and Valkanov (2009).
} 
and operating performance of acquiring companies. Results based on stock returns show that acquirers involved in large acquisitions continue to lose in the long-run, while small transactions eventually generate positive abnormal returns for acquiring shareholders. The post-acquisition operating performance of acquirers deteriorates only in large deals, suggesting that they fail to deliver the assumed synergies and produce bottom line improvements.

Overall our evidence suggests that while managers pay lower premia for large targets they still create less value for their shareholders. On the one hand, the fact that acquirers pay lower premiums is not supportive of the conjecture that they tend to overpay for large targets. In fact, a lower premium can, ceteris paribus, be perceived as an indication of a more rational acquisition decision that seeks to capture more benefits for acquirer shareholders. On the other hand, the fact that large acquisitions destroy more value for acquirers implies that they tend to be worse acquisition decisions. It appears that large deals are, on average, too big to succeed given the significant problems and corresponding costs associated with the postmerger integration process that end up hampering the realization of potential synergies.

Our study offers important contributions to the existing literature. First, we document a robust size effect in the market for corporate control; acquisitions of large targets are associated with significantly lower premiums. We find this negative association is considerably more pronounced than the positive effect of acquirer size on premiums documented by Moeller, Schlingemann and Stulz (2004). ${ }^{7}$ Second, we show that, despite the payment of lower premiums, acquisitions of large targets destroy more value for acquirers both in the short- and long-run and have lower expected synergy gains. This suggests that large acquisitions are more likely to fail to deliver the assumed synergies and that the problems associated with those transactions tend to outweigh any potential benefits from

\footnotetext{
${ }^{7}$ Moeller et al. (2004) argue that large acquirers pay higher premiums than small acquirers because managers of large firms are more likely to be infected by hubris.
} 
paying less. Our evidence attests that shareholder gains are not necessarily inversely related to the offer premium, as conventionally assumed. Finally, our study has implications for investment strategies based on takeover likelihood models. Palepu (1986) documents that the probability of being acquired is higher for smaller firms. Our findings suggest that takeover prediction based strategies that place more weight on smaller firms can be more profitable not only because of the higher probability of smaller firms being acquired but also because of the higher premiums they normally receive.

The remainder of this paper is organized as follows. Section II describes the data and methodologies used in our investigation and present the sample statistics. Section III examines the association between target size, takeover premium and the investors' response to acquisition announcements. Section IV, explores the relation between target size and longrun returns and operating performance of acquiring companies. Finally, Section V provides concluding remarks.

\section{Data, Methodology and Sample Statistics}

\section{A. Data and Sample Selection}

The sample of acquisitions is from Thomson Financial SDC and includes U.S. completed deals announced between 1990 and 2007, where the target is publicly-listed and the acquirer is either public or private. Spin-offs, recapitalizations, self-tenders, repurchases, minority stake purchases, acquisitions of remaining interest, exchange offers and privatizations are omitted. The transaction value is at least $\$ 1$ million and the acquirer owns less than $10 \%$ of the target's shares prior to the acquisition announcement and more than $50 \%$ at the deal completion. Targets are listed on NYSE, AMEX or NASDAQ and have data available on CRSP and Compustat. The final sample consists of 3,691 acquisitions of listed targets. 


\section{B. Measure of Target Size and Sample Distribution}

We partition the sample in three groups based on the size of the target firm relative to a market median. Market-Relative Target Size (MRTS) is the market capitalization of the target one month prior to the acquisition announcement divided by the median market value of all NYSE, AMEX and NASDAQ firms listed in Compustat at the announcement year. ${ }^{8}$

Table I presents the sample distribution by MRTS and year of announcement. Statistics reflect that takeover activity built-up progressively throughout the 1990s and reached record levels in 1999. During this period, the number of transactions was roughly equally distributed across the three different target size subsets. The level-off in activity amid the 2001-2002 recession was associated with a significant decline in large target deals as participants in the market for corporate control refrained from committing funds towards acquisitions of larger companies. The takeover market started recovering from its trough in 2003 and since then has approached activity levels approximately half of those achieved during the overheated market of the technology bubble. In recent years, the number of large target deals has again increased, while the share of transactions involving small targets has gradually decreased since 2001 .

[Please Insert Table I About Here]

\section{Sample Statistics}

Table II presents information on the 20 largest deals in our sample based on MRTS. The market capitalization of Time Warner was approximately 387.65 times larger than the median market value of U.S. firms listed on NYSE, AMEX and NASDAQ in 2000. Large

\footnotetext{
${ }^{8}$ The direction of our results remains unchanged when i) partitioning the sample by an Industry-Relative Target Size (IRTS) measure, defined as the ratio of the target's market value to the median market value of NYSE, AMEX and NASDAQ firms listed in Compustat within the corresponding Fama and French industry at the announcement year, ii) using CRSP market capitalization terciles to divide target firms into size subsets, iii) partitioning the sample in five size groups, instead of three, iv) using target total assets instead of market value as a measure of size and v) using target-to-acquirer relative size instead of target size.
} 
acquirers such as AT\&T, Pfizer, Bell Atlantic and J.P. Morgan Chase (including its predecessor) are listed multiple times among the buyers of the largest target firms. In line with previous evidence that takeover activity clusters by industry and over time (Harford, 2005; Andrade, Mitchell and Stafford, 2001), the reported transactions are primarily nondiversifying deals in Communications, Banking and the Pharmaceutical Industry with announcement dates between 1998 and 2000. Particularly compelling is the observation that, in 17 of the 20 largest transactions, the offer premium is below the average premium paid for targets in the same industry/year. ${ }^{9}$

[Please Insert Table II About Here]

Table III reports firm and deal statistics for our sample of acquisitions. Transactions are classified in small, medium and large target size subsets according to MRTS. The target's market and total asset value as well as the transaction value (all in 2007 dollars) increase with MRTS. The average (median) target in the large MRTS-group has a market value of about $\$ 3.1$ billion ( $\$ 1$ billion) and is acquired at a deal value of approximately $\$ 4.5$ billion $(\$ 1.5$ billion). This subset encompasses $92 \%$ of the total value spent on all deals in our sample. There is also a positive association between acquirer and target size, while large targets account for approximately $55 \%$ of the size of the acquirer compared to an average relative size of about $28 \%$ for small target deals. Tobin's $q$ (ACQUIRQ and TARGETQ) is the market value of assets divided by the book value of assets. ${ }^{10}$ It appears that in large acquisitions both acquirers and targets are relatively more overvalued (Jensen, 2005; Moeller, Schlingemann and Stulz, 2005) or employ better management teams (Servaes, 1991; Lang, Stulz and

\footnotetext{
${ }^{9}$ Premium is the ratio of the offer price to the target's share price one month prior to the acquisition announcement. Industry classifications are based on the updated Fama and French 49 industries. We thank Kenneth French for making this data available. Fama and French (1997) use 48 difference industry groups, but the authors have subsequently updated these to include 49 industries. For further information, see Kenneth French's website.

${ }^{10}$ Tobin's $q$ is calculated as the book value of assets minus common equity plus the market value of equity, divided by the book value of assets.
} 
Walkling, 1989). Inside ownership (INSIDE) is the percentage ownership of the target's directors and executives excluding the holdings of directors representing outside institutions, corporations and/or individual blockholders, following Bauguess et al. (2009). ${ }^{11}$ Insiders of large targets own significantly smaller stakes in their firms relative to directors and executives of small targets where managerial ownership is more concentrated. Moreover, large targets are less likely to be financially distressed than small targets, based on Altman (1968) Z-Scores (DISTRESS). ${ }^{12}$ HUBRIS is the percentage of acquiring firm managers that do not exercise vested stock options although they are at least $67 \%$ in-the-money. ${ }^{13}$ Based on this measure, managers that acquire large targets do not appear to be more overconfident than managers that acquire small targets. Further, large targets are considerably older firms (based on the age of the target; TARAGE) and are more likely to be acquired in unsolicited transactions (HOSTILE). Not surprisingly, acquisitions by private acquirers (PRIVACQ) are more concentrated in the small target subset, as private companies are likely to be more constrained in raising the necessary capital for acquisitions of sizeable targets than trade buyers. Also, large firms attract less competing bidders (COMPETE) than smaller firms. With regard to the method of payment, large (small) targets are more likely to be acquired with stock (cash), in line with DeAngelo, DeAngelo and Rice (1989) and Faccio and Masulis (2005). Moreover, the equity stake included in offers for large targets is on average $60 \%$, compared to only $45 \%$ for small target deals.

\section{[Please Insert Table III About Here]}

\footnotetext{
${ }^{11}$ Ownership data is collected from definitive 14A filings (proxy statements) of the target firm, filed with the U.S. Securities and Exchange Commission (SEC) preceding the acquisition announcement. The ownership sample includes transactions with announcement dates between 1998 and 2007.

${ }^{12}$ Using the Ohlson (1980) O-Score to measure financial distress produces similar results.

${ }^{13}$ We construct the stock option-based measure of overconfidence ('Holder67') as in Malmendier and Tate (2005). Data on executive stock options is from proxy statements (DEF 14A) of the acquiring firm, filed with the U.S. Securities and Exchange Commission (SEC).
} 
Table III also reports acquisition premiums. We use three alternative premium measures: i) the ratio of the offer price to the target's share price one month prior to the acquisition announcement $(P R E M)$, ii) the ratio of the offer price to the 30 -day $(-45,-15)$ volume-weighted average of the target's trading price (PREMVW) and iii) the cumulative abnormal return to target shareholders calculated over a 190-day $(-63,+126)$ window around the deal announcement (PREMR), as in Schwert (2000). We calculate overpayment (OVERPAY) as the offer premium (PREM) minus the mean premium paid for targets in the same industry (based on Fama and French 49 industries) at the announcement year and the year prior to the acquisition announcement. Target cumulative abnormal returns (TCAR3) are reported for a 3 -day $(-1,+1)$ announcement window. ${ }^{14}$ Remarkably, the mean premium (PREM) for large targets is only $38 \%$ compared to $54 \%$ for small targets. Thus, acquirers pay about $30 \%$ lower premiums for large than for small targets. Differences for PREMVW, PREMR and TCAR3 are similar. OVERPAY is negative for large and positive for small target firms, indicating that acquirers are less likely to pay too much when they buy large targets. Despite the fact that acquirers pay lower premia for large targets, they destroy more value for their shareholders around the deal announcement. Mean acquirer abnormal returns (ACAR3 and ACAR41) are negative and statistically significant only in the medium and large target size subsets. The mean abnormal return differential between acquirers of large and small targets is $-2.37(-4.83)$ percentage points for a 3-day (41-day) window. ${ }^{15}$ Consequently, the combined firm return around the deal announcement $(C O M B I)$ is also negatively related to target size, as the mean return from large target acquisitions $(0.55 \%)$ is significantly lower than the combined return achieved in deals involving smaller targets $(1.82 \%)$. We further

\footnotetext{
${ }^{14}$ Market model parameters are estimated over a 200-day interval preceding the event window using benchmark returns of the CRSP value-weighted market index. Alternative parameter estimation windows do not significantly affect our results. PREM and PREMVW are reported for values between zero and two, as in Officer (2003). Our results are similar when this premium restriction is not imposed.

${ }^{15}$ According to unreported findings, the large negative differential in acquirer returns (ACAR3 and ACAR41) between the large and small target size subsets persists irrespective of the method of payment.
} 
examine the relation between target size, acquisition premiums and acquirer returns in the next section, where we also control for deal, firm and market characteristics.

\section{Target Size, Premiums and Investor Reaction}

\section{A. Target Size and Premiums over Time}

The sample distribution in Table I shows that merger activity varies significantly over time. The number of transactions in our sample ranges from 71 in 1990 to 377 in 1999. Also, the sample covers the aftermath of the decade of hostile bust-up takeovers in the 1980s (Mitchell and Mulherin, 1996), the decade of deregulation in the 1990s (Andrade et al., 2001) as well as the recession following the burst of the technology bubble and the lead-up to the sixth merger wave driven primarily by high corporate cash balances and low-interest financing. It is, therefore, important to examine whether the differences in premiums reported in Table III are driven by any particular time period.

Figure I shows that although offer premiums change throughout the sample period, they are always lower in acquisitions of large firms. ${ }^{16}$ The smallest difference in premiums between large and small deals is observed in the second half of the 1990s and after 2003. Interestingly, for all three measures, premiums for small targets increase dramatically between 2000 and 2002, whereas premiums for large targets drop significantly. This may reflect the reluctance of acquirers to commit funds towards acquisitions of larger companies during recessions and their preference for small targets for which they are seemingly willing to pay more. However, there is a major drop in premiums for small targets after 2002.

[Please Insert Figure I About Here]

\footnotetext{
${ }^{16}$ Figure I depicts mean takeover premia. Patterns for medians are similar.
} 


\section{B. Premium Regressions}

In this section, we examine the relation between the offer premium and target size in a multivariate framework to control for other known deal-, firm- and market-related premium determinants. Table IV reports estimates from OLS regressions where the dependent variable is either the offer premium (regressions 1 to 15$)$ or the 3 -day $(-1,+1)$ target abnormal return TCAR3 (regressions 16 to 20). Offer premium is measured by PREM, PREMVW and PREMR as described previously. ${ }^{17}$ The main explanatory variable in all regressions is the natural logarithm of Market-Relative Target Size (LNMRTS). ${ }^{18}$ The corresponding coefficient estimates in regression specifications (1), (6), (11) and (16) are negative and statistically significant at the $1 \%$ level.

\section{[Please Insert Table IV About Here]}

Bargeron, Schlingemann, Stulz and Zutter (2008) show that unlisted acquirers offer significantly lower premiums than their publicly-listed counterparts. Although private acquirers are normally involved in smaller deals, making it unlikely that the listing status can drive our results, we still control for this listing effect. The indicator variable PRIVATE, taking the value of one when the acquirer is private and zero otherwise, has a negative and statistically significant coefficient for regression specifications (2), (7), (12) and (17), corroborating that private acquirers pay lower premiums. Moreover, takeover premiums tend to increase with the degree of competition in the market for corporate control (Walkling and Edminster, 1985; Alexandridis et al., 2010) and the level of takeover hostility (Schwert, 2000). Thus, we include variables that account for competition (ACTIVITY) and

\footnotetext{
${ }^{17}$ Performing the regressions with $O V E R P A Y$ as our dependent variable produces similar results.

${ }^{18}$ As MRTS ranges between 0.0038 and 387.65, we use its natural logarithm (LNMRTS). However, we obtain similar results using raw values.
} 
hostile/unsolicited offers (HOSTILE). ${ }^{19}$ Results show that hostile acquisitions are associated with significantly larger takeover premiums, while the impact of competition is ambiguous.

Statistics in Table III show that large (small) target firms are less likely to be acquired with cash (stock). Huang and Walkling (1987) and Savor and Lu (2009) document that premiums in cash-financed acquisitions are larger than those paid in share-for-share transactions, as target shareholders are to be compensated for the immediate tax implications of cash offers. ${ }^{20}$. The indicator variable $A L L C A S H$ controls for this effect and is equal to one in pure-cash deals and zero otherwise. Results for the offer premium (PREM and PREMVW) do not provide support for the tax compensation effect. Instead, it appears that there is a premium discount associated with cash payments. However, returns for target firms (TCAR3) are higher in cash offers, possibly reflecting the higher likelihood of deal completion. ${ }^{21}$

We also add a corporate diversification indicator variable (DIVERS) to control for the fact that higher premiums are normally offered in intra-industry mergers (Officer, 2003). This variable takes the value of one if the acquirer and target firms have different 2-digit SIC codes and zero otherwise. The coefficient of DIVERS is statistically insignificant in most specifications. Furthermore, Table III indicates that a greater fraction of large deals are announced during high market valuation periods, compared to small deals. Similarly, Table I shows that the market for corporate control is most active around the peak of the technology bubble, a high market valuation period. Bouwman, Fuller and Nain (2009) report that acquisitions destroy more value for acquirers during periods of high market valuation, but do not find evidence that this can be attributed to higher premiums. We include an indicator variable $(H I V A L)$, which is equal to one if the acquisition is announced within a high-

\footnotetext{
${ }^{19}$ ACTIVITY is the ratio of the number of listed firms targeted in successful acquisitions within an industry at the announcement year to the number of all firms listed on Compustat within the corresponding target industry and announcement year. Using instead an indicator variable that controls for the presence of competing takeover bids collected from SDC produces similar results.

${ }^{20}$ On the other hand, Fishman $(1988,1989)$ and Berkovitch and Narayanan (1990) develop models where the probability of competing bids, which can lead to higher takeover premiums, is lower when the initial bidder opts for payment in cash. This may suggest that acquisition premiums in stock-for-stock offers are higher than those paid in cash transactions.

${ }^{21}$ See for example Fishman (1989), Jennings and Mazzeo (1993) and Campa and Hernando (2009).
} 
valuation market, based on a de-trended monthly P/E ratio of the S\&P500 Index, and zero otherwise. In line with Bouwman et al. (2009), estimates provide some support that acquirers pay lower premiums in periods where the market is more highly valued. ${ }^{22}$

Roll (1986) posits that "hubris-infected" acquirers pay higher premiums. Similarly, Malmendier and Tate (2008) argue that managerial over-optimism leads to overpayment and, thus, results in value-destroying acquisitions. We proxy for managerial hubris using serial acquisitiveness, in line with Billet and Qian (2008). The serial acquirer indicator variable (SERIAL) takes the value of one if the acquirer makes two or more acquisitions within five years and zero otherwise. We find no evidence that frequent acquirers pay higher premiums. Moeller et al. (2004) argue that larger acquirers overpay since managerial hubris is more of a problem in large firms. Thus, we include the natural logarithm of the acquirer market value one month prior to the acquisition offer $(A S I Z E)$. Its coefficient is positive and statistically significant as predicted. Dong, Hirshleifer, Richardson, and Teoh (2006) report that acquirer and target firm valuations are associated with the size of the premium. ${ }^{23}$ We use the Tobin's $q$ of both the acquirer and target (ACQUIRQ and TARGETQ), but do not find a consistent pattern. Bauguess et al. (2009) document a positive relation between target returns and inside managerial ownership. INSIDE is the percentage ownership of all directors and executives of the target excluding those that represent outside institutions. Its coefficient is positive and statistically significant at the $1 \%$ level when regressed alone against PREM, PREMVW, PREMR and TCAR3, but becomes insignificant when accounting for all other explanatory

\footnotetext{
${ }^{22}$ Nathan and O'Keefe (1989) show a negative relation between acquisition premiums and the business cycle. If stock market performance moves ahead or parallel to the business cycle, then lower premiums will be paid in periods of positive market run-up. We measure market performance $(R U N U P)$ using the buy-and-hold return of the S\&P500 index for the six months $(-126,-5)$ prior to the acquisition announcement. When we replace $H I V A L$ with the buy-and-hold return of the S\&P500 index for the six months $(-126,-5)$ prior to the acquisition announcement, we find a negative relation between stock market performance and the offer premium.

${ }^{23}$ Dong et al. (2006) show for example that highly-valued targets receive lower bid premia and are, thus, subject to lower abnormal returns. Given that large targets are more highly-valued (Table III), the negative relationship between target size and takeover premia may be driven by firm valuation.
} 
variables. Finally, we include year and industry dummies (YEAR FE and INDUSTRY FE) to control for associated fixed effects on the offer premium. ${ }^{24}$

Most importantly, the coefficient of LNMRTS remains negative and statistically significant at the $1 \%$ level, in all specifications and irrespective of what other control variables are included in the regression. It can independently explain more variation in acquisition premiums than any other single variable discussed above. Therefore, the negative association between target size and the acquisition premium is not driven by other known deal, firm and market characteristics.

\section{Acquirer Return Regressions}

In this section, we test the robustness of the negative association between target size and acquirer returns documented in Table III. Table V reports results from multivariate regressions where the dependent variable is the 3- or 41-day acquirer abnormal return (ACAR3 and ACAR41). The main explanatory variable is the natural logarithm of MarketRelative Target Size (LNMRTS), while we also control for effects that have been shown to explain returns to acquiring firms.

\section{[Please Insert Table V About Here]}

Bradley, Desai and Kim, (1988) and Schwert (2000) report that acquirer abnormal returns are negatively associated with bidder competition and takeover hostility, respectively. Therefore, we include variables to control for takeover competition (ACTIVITY) and hostile/unsolicited offers (HOSTILE), but their coefficients are statistically insignificant. Travlos (1987) documents that stock-swap offers result in more negative abnormal returns for

\footnotetext{
${ }^{24}$ In unreported univariate tests, we group target firms using the Fama/French 5 industry classification and augment this to examine the financial sector separately. On average, the lowest premia (PREM) are paid for targets within the financial (39.6\%) and manufacturing (40.8\%) sectors, while the highest are paid for technology targets $(52.3 \%)$. However, irrespective of the industry grouping, we find that shareholders of large (small) targets receive significantly lower (higher) premiums and consequently earn lower (higher) abnormal returns around the acquisition announcement.
} 
acquirers than cash payments. The coefficient of an all-equity indicator (ALLSTOCK) is negative and statistically significant at the $1 \%$ level in most specifications. The inter-industry indicator (DIVERS) accounts for the fact that diversifying acquisitions are found to destroy shareholder value (Morck et al., 1990). Further, we do not find that market valuation (HIVAL) at the time of the merger matters, as suggested by Bouwman et al. (2009. Moreover, we control for the presence of serial acquirers (SERIAL), as Fuller, Netter and Stegemoller (2002) and Billet and Qian (2008) document lower abnormal returns for frequent bidders.

We also use the natural logarithm of the acquirer's market capitalization one month prior to the acquisition announcement (ASIZE) to control for the fact that small acquirers tend to outperform large ones (Moeller et al., 2004). Although the evidence reported here points to a positive or insignificant association between acquirer size and abnormal returns, we too find a negative relation when returns are regressed on ASIZE alone. However, the sign and/or significance of acquirer size changes when we add LNMRTS in the regression model, indicating that the two variables are correlated. ${ }^{25}$ In Section F, we examine the relative effect of acquirer and target size on acquirer returns and premiums.

Previous research has shown that bidder and target valuations can affect returns to acquiring firms (Moeller et al., 2005; Servaes, 1991; Lang, Stulz and Walkling, 1989). Thus, we include the Tobin's $q$ of both acquirers and targets (ACQUIRQ and TARGETQ) in our regressions. In line with Moeller et al. (2004, 2005), we find evidence of significantly lower abnormal returns to high $q$ acquirers around the deal announcement. However, the Tobin's $q$ of the target is statistically insignificant in all specifications. Finally, we include industry and year fixed effects (INDUSTRY FE and YEAR FE) to account for possible biases from industry- and time-clustering of merger activity. The coefficient of LNMRTS is negative and statistically significant at the $1 \%$ level in all specifications. Consistent with other studies, we find a robust negative association between target size and gains to acquirer shareholders.

\footnotetext{
${ }^{25}$ Their correlation is $60.29 \%$ and statistically significant at the $1 \%$ level.
} 


\section{Target Size and Uncertainty Change}

Although lower premiums are offered for large targets relative to small targets, investors are more averse to large deal proposals. This implies that they are thoroughly concerned about the difficulties of acquiring large targets and the materialization of the promised synergies. Fuller, Netter and Stegemoller (2002) argue that acquiring firms may find it more difficult to integrate larger targets into their business and experience from past mega-deals attests this conjecture.

If investors are more uncertain about large target acquisitions, then this ambiguity should be reflected in their trading pattern. Thus, we use the acquirer idiosyncratic return volatility to estimate the level of uncertainty related to the firm's profitability (as in Pastor and Veronesi, 2003; Wei and Zhang, 2003). Accordingly, large target acquisitions should be associated with a more pronounced increase in the idiosyncratic volatility of the acquiring firm relative to transactions involving small targets. We estimate the change in return uncertainty $(\triangle U N C)$ as the percentage difference in the acquirer's idiosyncratic return volatility between the periods preceding the acquisition announcement $(-200,-20)$ and following the announcement $(-2,+178) .{ }^{26}$ Table VI reports mean and median $\triangle U N C$-values for the three MRTS subsets. Investor uncertainty increases on average by more than $11 \%$ following announcements of large acquisitions and only by $3.54 \%$ after offers involving smaller targets. The difference between these estimates is statistically significant at the $1 \%$ level. The median uncertainty change for the small MRTS-subset is statistically insignificant, which implies that for more than half of the transactions in this group investor uncertainty remains unchanged. To gain further insight, we regress $\triangle U N C$ on the natural logarithm of MRTS and obtain the following result:

$$
\Delta U N C=\underset{(p=0.00 \emptyset}{0.080}+\underset{(p=0.00 \emptyset)}{0.019} \times L M M R I S
$$

\footnotetext{
${ }^{26}$ Idiosyncratic volatility is the standard deviation of the daily market-adjusted residuals.
} 
Consequently, acquirer return uncertainty increases sharply with target size as investors are more ambiguous about the success of large target deals.

[Please Insert Table VI About Here]

\section{E. The Relative Effect of Target and Acquirer Size}

Given the importance of acquirer size in explaining both premiums and acquirer returns (Moeller et al., 2004) as well as the fact that it tends to increase with the size of the target, it is important to examine the relative effect of both the acquirer and target size. Table VII reports offer premiums (Panel A) and abnormal returns to acquiring firms (Panel B) by MRTS and MRAS (Market-Relative Acquirer Size) terciles. For the entire sample, we find no significant relation between acquirer size and takeover premiums. On the other hand, the 'large' minus 'small' target size difference in average premiums is -17.23 percentage points and statistically significant at the $1 \%$ level. Although the acquirer size effect becomes significant within each individual target size subset, the negative 'large' minus 'small' target size differences in premiums are much more pronounced than the positive 'large' minus 'small' acquirer size differences. Small (large) acquirers offer a mean premium of over 54\% (63\%) for small targets, but only $28 \%(41 \%)$ for large targets. This suggests that the target size effect overpowers the acquirer size effect on acquisition premiums.

\section{[Please Insert Table VII About Here]}

Acquirer returns are negatively related with target size, but the evidence on acquirer size is inconclusive: some estimates reflect a negative and some a positive relation. The average (median) 'high' minus 'low' target size difference in acquirer returns for the entire sample is $-2.37(-1.49)$ percentage points, reflecting a more pronounced negative association relative to the return differences based on $M R A S$ of $-0.64(0.40)$ percentage points. 
Consequently, acquisitions of large targets seem to destroy more shareholder value compared to acquisitions by large acquirers.

\section{Do Large Deals Destroy More Value in the Long-Run?}

\section{A. Target Size and Acquirer Long-Run Returns}

Although we show that investors display greater uncertainty about large target deals and tend to penalize acquirers more around the acquisition announcement, this does not necessarily tell us whether acquirers ultimately destroy more value for their shareholders. Myopic investors may overreact to large deal announcements in the short-run, ignoring the considerably lower premiums. In this case, long-run returns to acquiring shareholders would be higher as the large deal discount is eventually channeled into shareholder gains. Conversely, if investors' initial reaction is efficient then acquirers should continue to lose value following large deals.

Table VIII reports long-run abnormal returns to acquiring firms by target size. We calculate monthly percentage estimates of acquirer abnormal returns from Calendar Time Portfolio Regressions (CTPR) for event periods of 12 and 36 months. ${ }^{27}$ The monthly acquirer abnormal return is calculated using time series regressions of the following form:

$R_{p t}-R_{f t}=\alpha_{i}+\beta_{i}\left(R_{M t}-R_{f t}\right)+s_{i} S M B_{t}+h_{i} H M L_{t}+u_{i} U M D_{t}+\varepsilon_{i t}$, where the dependent variable, $R_{p t}-R_{f t}$, is the equally-weighted, monthly calendar time portfolio excess return and the independent variables are the Fama and French (1993) and Carhart (1997) factors. ${ }^{28}$ Calendar months with less than 10 return observations are excluded from the regressions. ${ }^{29}$

[Please Insert Table VIII About Here]

\footnotetext{
${ }^{27}$ We follow the methodology outlined in Lyon, Barber and Tsai (1999).

${ }^{28}$ The Fama and French (1993) and Carhart (1997) factors are taken from Kenneth French's website.

${ }^{29}$ In an unreported test, we exclude acquirers involved in more than one acquisition within the 12 or 36 months return window and find similar results.
} 
Results show that long-run acquirer returns are also negatively associated with the size of the target firm. Small target deals result in acquirer abnormal gains of about $2.64 \%$ (insignificant) and $8.64 \%$ (significant at $10 \%$ level) for the one and three year period following the deal completion month, respectively. Acquirers that buy large targets, on the other hand, experience a 12-month (36-month) abnormal return of $-3.40 \%(-7.02 \%)$, statistically significant at the 5\% (10\%) level. Moreover, 'large' minus 'small' abnormal return differentials based on zero investment portfolio alphas are negative and statistically significant at conventional levels. Therefore, there is clear evidence that large target acquirers continue to underperform small target acquirers in the long-run despite the lower premiums paid in large target transactions. This provides support to the conjecture that large acquisitions are more likely to fail, irrespective of the size of the premium.

\section{B. Target Size and Acquirer Operating Performance}

In the previous section, we show that acquirers of large targets continue to lose significantly more shareholder value than acquirers of small targets. If this is due to the complexity of implementing large deals that ends up discounting potential synergies from the combination, it should be reflected in the acquirers' post-event profitability. While Healy, Palepu and Ruback (1992) and Andrade et al. (2001) find significant acquisition-induced improvements in the operating performance of the acquiring company (relative to the firm's industry median), Ghosh (2001) fails to record significant changes in post-acquisition operating performance. We calculate pre- and post-acquisition return on assets in order to analyze the effect of target size on the acquirer's ability to implement the transaction and generate earnings from the assets of the combined company. In line with the negative association between target size and acquirer returns, we expect the operating performance of acquirers involved in large deals to be worse than the operating performance of small target acquirers. 
Table IX reports raw (ROA) and industry-adjusted (IAROA) median returns on assets for the three MRTS-subsets for up to three years before and after the year of the acquisition announcement. Return on assets is the ratio of operating income to the book value of total assets. ${ }^{30}$ We calculate pre-acquisition pro-forma return on assets for the combined firm based on weighted averages of target and acquirer returns, with the relative asset values being the respective weights. ${ }^{31}$ While acquirers of large targets generate higher returns from the use of their assets (9-12\%) than small target acquirers (3-5\%), acquirers of large target firms struggle to achieve their level of pre-acquisition operating performance. In fact, the median ROA of $9.45 \%$ over the three years following the large target acquisition is significantly lower than the three-year pre-acquisition return of $11.86 \%$. Acquirers of small targets, however, experience no significant change in their operating performance, suggesting that large deals present acquirers with significant implementation problems. The direction of the results based on IAROA are similar.

\section{[Please Insert Table IX About Here]}

To further examine the impact of the target size on the acquirer's profitability, we regress the difference between post- and pre-acquisition $R O A(\triangle R O A)$ on the natural logarithm of MRTS and obtain the following results: ${ }^{32}$

$$
\Delta R O A=\underset{(p=0.000}{0.0098}-\underset{(p=0.000)}{0.0053} \times L M M R I S
$$

Consequently, the acquiring firm's post-acquisition performance decreases in the size of the target firm.

\footnotetext{
${ }^{30}$ Using net income instead of operating income for the calculation of $R O A$ does not change the direction of our results.

${ }^{31}$ For the calculation of pre- and post-acquisition operating performance, see Healy, Palepu and Ruback (1992).

${ }^{32}$ Results are similar when $\triangle I A R O A$ is the dependent variable.
} 


\section{Conclusion}

We have shown that acquirers of large targets pay significantly lower premiums. This negative relation between target size and acquisition premiums remains robust after controlling for other premium determinants identified in the extant empirical literature. We have also established that large transactions result in more severe wealth destruction for acquiring shareholders as well as sharper increases in acquirer return uncertainty around the deal announcement, implying that investors perceive large acquisitions as more uncertain projects. Large targets continue to lose value in the long-run as opposed to acquirers of small targets that generate positive abnormal returns for their shareholders. In addition, the postacquisition operating performance of acquirers deteriorates only following large deals. Overall, our results are largely inconsistent with conjectures relating the failure of mega deals to systematic overpayment. Instead, they suggest that the complexity of large deals can make it more unlikely that they offer any economic benefits despite the fact that they are associated with lower premiums. 


\section{References}

Alexandridis, G., Petmezas, D. and N.G. Travlos, 2010, 'Gains from M\&As around the World: New Evidence', Financial Management (forthcoming).

Altman, E.I., 1968, 'Financial Ratios, Discriminant Analysis, and the Prediction of Corporate Bankruptcy', Journal of Finance 23, 589-609.

Andrade, G., Mitchell, M. and E. Stafford, 2001, 'New Evidence and Perspectives on Mergers', Journal of Economic Perspectives 15, 103-120.

Atiase, R.K., 1985, ' Predisclosure Information, Firm Capitalization and Security Price Behavior around Earnings Announcements', Journal of Accounting Research 23, 2135.

Bargeron, L., Schlingemann, F.P., Stulz, R.M. and C.J. Zutter, 2008, 'Why Do Private Acquirers Pay So Little Compared to Public Acquirers?', Journal of Financial Economics 89, 375-390.

Bauguess, S.W., Moeller, S.B., Schlingemann, F.P. and C.J. Zutter, 2009, 'Ownership Structure and Target Returns', Journal of Corporate Finance 15, 48-65.

Bayazitova, D., Kahl, M. and R. Valkanov, 2009, 'Which Mergers Destroy Value? Only Mega-Mergers', SSRN Working Paper.

Berger, P. and E. Ofek, 1995, 'Diversification's effect on firm value', Journal of Financial Economics 37, 39-65.

Berkovitch, E. and M.R Narayanan. 1990, 'Competition and Medium of Exchange in Takeovers', Review of Financial Studies 3, 153-174.

Billet, M.T. and Y. Qian, 2008, 'Are Overconfident CEOs Born or Made? Evidence of SelfAttribution Bias from Frequent Acquirers', Management Science 54, 1037-1051.

Bouwman, C.H., Fuller, K.P. and A.S. Nain, 2009, 'Market Valuation and Acquisition Quality: Empirical Evidence, Review of Financial Studies 22, 633-679.

Bradley, M., Desai, A. and E.H. Kim, 1988, 'Synergistic Gains from Corporate Acquisitions and their Division between the Stockholders of Target and Acquiring Firms', Journal of Financial Economics 21, 3-40.

Brown, S.J. and J.B. Warner, 1985, 'Using Daily Stock Returns - The Case of Event Studies', Journal of Financial Economics 14, 3-31.

Campa, J.M. and I. Hernando, 2009, 'Cash, Access to Credit, and Value Creation in M\&As', Working Paper.

Carhart, M.M., 1997, 'On the persistence in mutual fund performance', Journal of Finance $52,57-82$.

Chang, X., Dasgupta, S. and G. Hilary, 2006, 'Analyst Coverage and Financing Decisions', Journal of Finance 61, 3009-3048.

Collins, D.W., Kothari, S.P. and J.D. Rayburn, 1987, 'Firm Size and the Information Content of Prices with respect to Earnings', Journal of Accounting and Economics 9, 111-138.

Cools, K., Gell, J., Kengelbach, J. and A. Roos, July 2007, 'A Brave New World of M\&A: How to Create Value from Mergers and Acquisitions', The Boston Consulting Group.

Datta, D.K., 1991, 'Organizational Fit and Acquisition Performance: Effects of PostAcquisition Integration', Strategic Management Journal 12, 281-297. 
Datta, S., Iskandar-Datta, M. and K. Raman, 2001, 'Executive Compensation and Corporate Acquisition Decisions', Journal of Finance 56, 2299-2336.

DeAngelo, H., DeAngelo, L. and E.M. Rice, 1984, 'Going Private: Minority Freezeouts and Stockholder Wealth', Journal of Law and Economics 27, 367-401.

Demsetz, H. and K. Lehn, 1985, 'The Structure of Corporate Ownership: Causes and Consequences', Journal of Political Economy 93, 1155-1177.

Dong, M., Hirshleifer, D., Richardson, S., and S-H. Teoh, 2006, 'Does Investor Misvaluation Drive the Takeover Market?', Journal of Finance 61, 725-762.

Faccio, M. and R.W. Masulis, 2005, 'The Choice of Payment Method in European Mergers and Acquisitions', Journal of Finance 60, 1345-1388.

Fama, E.F. and K. French, 1993, 'Common risk-factors in the returns on stocks and bonds', Journal of Financial Economics 33, 3-56.

Fishman, M.J., 1988, 'A Theory of Preemptive Takeover Bidding', RAND Journal of Economics 19, 88-101.

Fishman, M.J., 1989, 'Preemptive Bidding and the Role of the Medium of Exchange in Acquisitions', Journal of Finance 44, 41-57.

Fuller, K.P., Netter, J. and M. Stegemoller, 2002, 'What Do Returns to Acquiring Firms Tell Us? Evidence from Firms That Make Many Acquisitions', Journal of Finance 57, 1763-1793.

Ghosh, A., 2001, 'Does Operating Performance Really Improve Following Corporate Acquisitions?', Journal of Corporate Finance 7, 151-178.

Gorton, G., Kahl, M. and R. Rosen, 2009, 'Eat or Be Eaten: A Theory of Mergers and Firm Size', Journal of Finance 64, 1291-1344.

Harford, J., 2005, 'What Drives Merger Waves?', Journal of Financial Economics 77, 529560.

Hasbrouck, J., 1985, 'The Characteristics of Takeover Targets: $q$ and other Measures', Journal of Banking \& Finance 9, 351-362

Hayward, M.L.A., 2002, 'When Do Firms Learn From Their Acquisition Experience? Evidence from 1990 to 1995', Strategic Management Journal 23, 21-39.

Healy, P.M., Palepu, K.G. and R.S Ruback, 1992, 'Does Corporate Performance Improve After Mergers?', Journal of Financial Economics 31, 135-175.

Henry, D. and F.F. Jespersen, 2002, 'Mergers: Why Most Big Deals Don't Pay Off', BusinessWeek, 14 October 2002, viewed 30 March 2010.

< http://www.businessweek.com/magazine/content/02_41/b3803001.htm > .

Huang, Y. and R. Walkling, 1987, 'Target Abnormal Returns Associated with Acquisition Announcements: Payment, Acquisition Form, and Managerial Resistance', Journal of Financial Economics 19, 329-349.

Jennings, R.H. and M.A. Mazzeo, 1993, 'Competing Bids, Target Management Resistance, and the Structure of Takeover Bids', Review of Financial Studies 6, 883-909.

Jensen, M.C., 2005, 'Agency Costs of Overvalued Equity', Financial Management, 5-16.

Lang, L.H.P., Stulz, R. and R.A. Walkling, 1989, 'Managerial performance, Tobin's $q$ and the gains from successful tender offers', Journal of Financial Economics 24, 137-155. 
Loderer, C. and K. Martin, 1990, 'Corporate Acquisitions by Listed Firms: The Experience of a Comprehensive Sample', Financial Management 19, 17-33.

Lyon, J.D., Barber, B.M. and C-L. Tsai, 1999, 'Improved Methods for Tests of Long-Run Abnormal Stock Returns', Journal of Finance 54, 165-201.

Malmendier, U. and G.Tate, 2005, 'CEO Overconfidence and Corporate Investment', Journal of Finance 60, 2661-2700.

Malmendier, U. and G.Tate, 2008, 'Who Makes Acquisitions? CEO Overconfidence and the Market's Reaction', Journal of Financial Economics 89, 20-43.

Mitchell, M.L. and J.H. Mulherin, 1996, 'The Impact of Industry Shocks on Takeover and Restructuring Activity', Journal of Financial Economics 41, 193-229.

Moeller, S.B., Schlingemann, F.P. and R.M. Stulz, 2004, 'Firm Size and the Gains from Acquisitions', Journal of Financial Economics 73, 201-228.

Moeller, S.B., Schlingemann, F.P. and R.M. Stulz, 2005, 'Wealth Destruction on a Massive Scale? A Study of Acquiring-Firm Returns in the Recent Merger Wave', Journal of Finance 60, 757-782

Morck, R., Shleifer, A. and R.W. Vishny, 1990, 'Do Managerial Objectives Drive Bad Acquisitions?', Journal of Finance 45, 31-48.

Nathan, K. and T. O'Keefe, 1989, 'The Rise in Takeover Premiums: An Exploratory Study', Journal of Financial Economics 23, 101-119.

Officer, M.S., 2003, 'Termination Fees in Mergers and Acquisitions', Journal of Financial Economics 69, 431-467.

Ohlson, J.A., 1980, 'Financial Ratios and the Probabilistic Prediction of Bankruptcy', Journal of Accounting Research 18, 109-131.

Palepu, K. G., 1986, 'Predicting Takeover Targets: A Methodological and Empirical Analysis', Journal of Accounting and Economics 8, 3-35.

Pastor, L. and P. Veronesi. 2003, 'Stock valuation and learning about profitability', Journal of Finance 58, 1749-1790.

Roll, R., 1986, 'The Hubris Hypothesis of Corporate Takeovers', Journal of Business 59, 197-216.

Savor, P.G. and Q. Lu, 2009, 'Do Stock Mergers Create Value for Acquirers?', Journal of Finance 64, 1061-1097.

Schwert, G.W., 2000, 'Hostility in Takeovers: In the Eyes of the Beholder?', Journal of Finance 55, 2599-2640.

Servaes, H., 1991, 'Tobin's $q$ and the gains from takeovers', Journal of Finance 46, 409-419.

Shrivastava, P., 1986, 'Postmerger Integration', Journal of Business Strategy 7, 65-76.

Travlos, N.G., 1987, 'Corporate Takeover Bids, Method of Payment, and Bidding Firms' Stock Returns', Journal of Finance 42, 943-963.

Walkling, R.A. and R.O. Edminster, 1985, 'Determinants of Tender Offer Premiums', Financial Analysts Journal 41, 27-37.

Wei, S. X., and C. Zhang, 2006, 'Why did individual stocks become more volatile?', Journal of Business 79, 259-292. 
Table I

Sample Distribution by Announcement Year and Target Firm Size

The sample includes completed, domestic U.S. mergers and acquisitions of public targets by private and public acquirers, announced between 1990 and 2007. Deals have transaction value of at least $\$ 1$ million and the acquirer owns less than $10 \%$ of the target shares prior to the announcement and more than $50 \%$ upon completion of the transaction. Target firms are listed on either NYSE, AMEX or NASDAQ and have data available on CRSP and Compustat. The sample is split into three groups (Small, Medium and Large) based on MRTS (Market-Relative Target Size) which is measured by the ratio of the market value of the target (in \$million) one month prior to the acquisition announcement and the median market value of all Compustat firms in the announcement year.

\begin{tabular}{ccccc}
\hline Year & S mall & Medium & Large & Total \\
\cline { 2 - 4 } 1990 & 28 & 22 & 21 & 71 \\
1991 & 36 & 25 & 30 & 91 \\
1992 & 34 & 37 & 24 & 95 \\
1993 & 51 & 49 & 37 & 137 \\
1994 & 61 & 74 & 53 & 188 \\
1995 & 84 & 77 & 71 & 232 \\
1996 & 86 & 95 & 81 & 262 \\
1997 & 97 & 147 & 117 & 361 \\
1998 & 123 & 118 & 122 & 363 \\
1999 & 108 & 133 & 136 & 377 \\
2000 & 92 & 88 & 124 & 304 \\
2001 & 108 & 62 & 56 & 226 \\
2002 & 63 & 45 & 27 & 135 \\
2003 & 77 & 53 & 34 & 164 \\
2004 & 56 & 49 & 50 & 155 \\
2005 & 43 & 56 & 70 & 169 \\
2006 & 41 & 55 & 80 & 176 \\
2007 & $\mathbf{1 2 3 0}$ & 46 & 97 & $\mathbf{3 9 1}$ \\
\hline Total & & $\mathbf{1 2 3 1}$ & & 185 \\
\hline
\end{tabular}




\section{Table II}

\section{Acquisition Premium and other Statistics for the 20 Largest Deals}

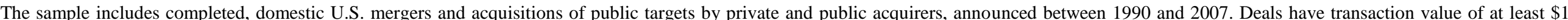

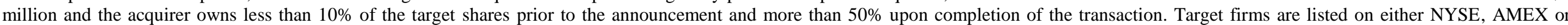

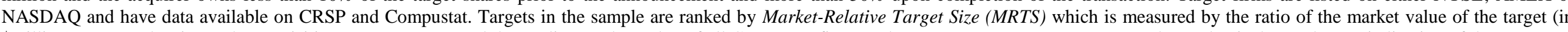

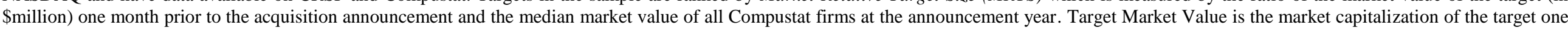

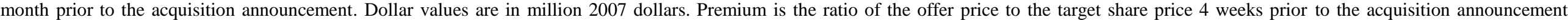
Industry premium is the mean premium paid for targets in the same industry at the announcement year.

\begin{tabular}{|c|c|c|c|c|c|c|c|c|c|}
\hline $\begin{array}{c}\text { Announcement } \\
\text { Date }\end{array}$ & $\begin{array}{l}\text { Acquirer } \\
\text { Name }\end{array}$ & $\begin{array}{l}\text { Acquirer } \\
\text { Industry }\end{array}$ & $\begin{array}{c}\text { Target } \\
\text { Name }\end{array}$ & $\begin{array}{c}\text { Target } \\
\text { Industry }\end{array}$ & $\begin{array}{c}\text { Target Market } \\
\text { Value }(2007 \$ m)\end{array}$ & $\begin{array}{c}\text { Market-Relative } \\
\text { Target Size } \\
\text { (MRTS) }\end{array}$ & $\begin{array}{c}\text { Deal Value } \\
(2007 \$ \mathrm{~m})\end{array}$ & Premium & $\begin{array}{l}\text { Industry } \\
\text { Premium }\end{array}$ \\
\hline 10.01 .2000 & America Online Inc & Communications & Time Warner & Entertainment & $93,685.28$ & 387.65 & $200,958.2$ & $70.19 \%$ & $56.78 \%$ \\
\hline 01.12 .1998 & Exxon Corp & Oil / Gas & Mobil Corp & Oil / Gas & $77,745.52$ & 299.65 & $101,721.7$ & $32.24 \%$ & $41.97 \%$ \\
\hline 06.04.1998 & Travelers Group Inc & Banking & Citicorp & Banking & $77,027.66$ & 296.88 & $93,491.2$ & $18.97 \%$ & $35.93 \%$ \\
\hline 13.04 .1998 & NationsBank Corp & Banking & BankAmerica Corp & Banking & $73,493.13$ & 283.26 & $79,414.6$ & $2.82 \%$ & $35.93 \%$ \\
\hline 04.11 .1999 & Pfizer Inc & Pharmaceuticals & Warner-Lambert Co & Pharmaceuticals & $75,244.40$ & 273.75 & $112,440.5$ & $40.82 \%$ & $61.91 \%$ \\
\hline 28.07 .1998 & Bell Atlantic Corp & Communications & GTE Corp & Communications & $69,456.07$ & 267.70 & $68,824.7$ & $-4.94 \%$ & $56.70 \%$ \\
\hline 15.07.2002 & Pfizer Inc & Pharmaceuticals & Pharmacia Corp & Pharmaceuticals & $57,801.84$ & 258.11 & $69,495.7$ & $12.76 \%$ & $89.05 \%$ \\
\hline 22.04.1999 & AT\&T Corp & Communications & MediaOne Group Inc & Communications & $50,892.85$ & 185.15 & $62,140.7$ & $22.83 \%$ & $49.32 \%$ \\
\hline 16.10 .2000 & Chevron Corp & Oil / Gas & Texaco Inc & Oil / Gas & $36,982.81$ & 153.03 & $52,295.6$ & $17.55 \%$ & $37.75 \%$ \\
\hline 07.09.1999 & Viacom Inc & Communications & CBS Corp & Communications & $41,743.32$ & 151.87 & $49,726.5$ & $1.73 \%$ & $49.32 \%$ \\
\hline 14.06 .1999 & Qwest Communications Inc & Communications & US WEST Inc & Communications & $39,499.03$ & 143.70 & $71,003.2$ & $49.77 \%$ & $49.32 \%$ \\
\hline 14.01.2004 & JPM organ Chase \& Co & Banking & Bank One Corp & Banking & $54,838.53$ & 135.86 & $65,239.3$ & $17.10 \%$ & $29.16 \%$ \\
\hline 20.12 .1999 & Monsanto Co & Pharmaceuticals & Pharmacia \& Upjohn Inc & Pharmaceuticals & $37,202.67$ & 135.35 & $33,398.8$ & $-13.50 \%$ & $61.91 \%$ \\
\hline 05.03 .2006 & AT\&T Inc & Communications & BellSouth Corp & Communications & $53,972.10$ & 126.22 & $75,723.2$ & $25.76 \%$ & $22.48 \%$ \\
\hline 22.04 .1996 & Bell Atlantic Corp & Communications & NYNEX Corp & Communications & $29,871.90$ & 122.73 & $28,585.9$ & $-5.68 \%$ & $48.40 \%$ \\
\hline 28.01 .2005 & Procter \& Gamble Co & Consumer Goods & Gillette Co & Consumer Goods & $47,908.99$ & 121.38 & $59,063.3$ & $20.45 \%$ & $39.05 \%$ \\
\hline 13.09 .2000 & Chase Manhattan Corp & Banking & JP Morgan \& Co Inc & Banking & $29,065.83$ & 120.27 & $40,929.9$ & $32.42 \%$ & $44.39 \%$ \\
\hline 04.09 .2001 & Hewlett-Packard Co & Computer Hardware & Compaq Computer Corp & Computer Hardware & $31,458.02$ & 120.18 & $29,967.5$ & $-2.00 \%$ & $59.15 \%$ \\
\hline 13.04 .1998 & BANC ONE Corp & Banking & First Chicago NBD Corp & Banking & $31,018.77$ & 119.55 & $38,160.3$ & $34.05 \%$ & $35.93 \%$ \\
\hline 31.07 .1995 & Walt Disney Co & Communications & Capital Cities/ABC Inc & Communications & $22,914.53$ & 108.80 & $25,964.6$ & $15.18 \%$ & $32.69 \%$ \\
\hline
\end{tabular}




\section{Table III: Descriptive Sample Statistics}

The sample includes completed, domestic U.S. mergers and acquisitions of public targets by private and public acquirers, announced between 1990 and 2007. Deals have transaction value of at least \$1 million and the acquirer owns less than 10\% of the target shares prior to the announcement and more than 50\% upon completion of the transaction. Target firms are listed on either NYSE, AMEX or NASDAQ and have data available on CRSP and Compustat. The sample is split into three groups (Small, Medium and Large) based on MRTS (Market-Relative Target Size) which is the ratio of the target's market value one month prior to the acquisition announcement and the median market value of all Compustat firms at the announcement year. $\mathrm{N}$ is the sample size. Acquirer (ASIZE) and target market values (TSIZE) refer to market capitalization one month prior to the announcement. Target total assets (TASSETS) are from the year end prior the acquisition announcement. Transaction value (DEALV), TASSETS, TSIZE and ASIZE are in million 2007 dollars. Relative size (RELSIZE) is the ratio of the target to the acquirer market value one month prior to the acquisition announcement. PREM is the ratio of the offer price to the target share price 4 weeks prior to the acquisition announcement for observations between zero and two. PREMVW is the ratio of the offer price to the 30 -day $(-45,-15)$ volume-weighted average of the target's trading price, reported for observations between zero and two. PREMR is the cumulative abnormal return to target shareholders calculated over for a 190-day $(-63,+126)$ window around the deal announcement. OVERPAY is the offer premium (PREM) minus the mean premium paid for targets in the same Fama/French industry at the announcement year and the year prior to the acquisition announcement. Cumulative Abnormal Returns for acquirers are calculated using 3-day $(-1,+1)$ and 41-day $(-20,+20)$ windows (ACAR3 and ACAR41) and for targets using a 3-day $(-1,+1)$ window (TCAR3) around the deal announcement day. COMBI is the combined, value-weighted 3 -day $(-1,+1)$ announcement period return of the acquirer and target firm. Tobin's $q$ (ACQUIRQ and TARGETQ) is the market value of assets over the book value of assets. INSIDE is the percentage ownership of all directors and executives of the target firm excluding those that represent outside institutions, corporations and individuals. TARAGE is the target's age in years. DISTRESS is the percentage of target firms with Altman (1968) Z-Scores below 1.80. HUBRIS is the percentage of acquiring firm managers with vested, unexercised stock options that are at least $67 \%$ in-the-money. DAYS is the number of days between the deal announcement and its completion. COMPETE is the percentage of deals with multiple takeover bids. HOSTILE is the percentage of hostile deals. DIVERS is the percentage of deals where the acquirer and target have different 2-digit SIC codes. HIGHVAL is the percentage of deals taking place within a high valuation market based on the de-trended, monthly P/E ratio of the S\&P500 Index. PRIVACQ is the percentage of deals where the acquirer is a private firm. PERCSHARES is the percentage of shares acquired. ALLCASH (ALLSTOCK) is the percentage of deals financed with $100 \%$ cash (stock) and HYBRID comprises all remaining transactions. CASH (STOCK) is the percentage of cash (stock) in the offer. Differences between the 'Large' and 'Small' subsets are based on two-sample t-tests for means and Wilcoxon-sign rank tests for medians. a, b, and c denote statistical significance at the $1 \%, 5 \%$ and $10 \%$ level, respectively.

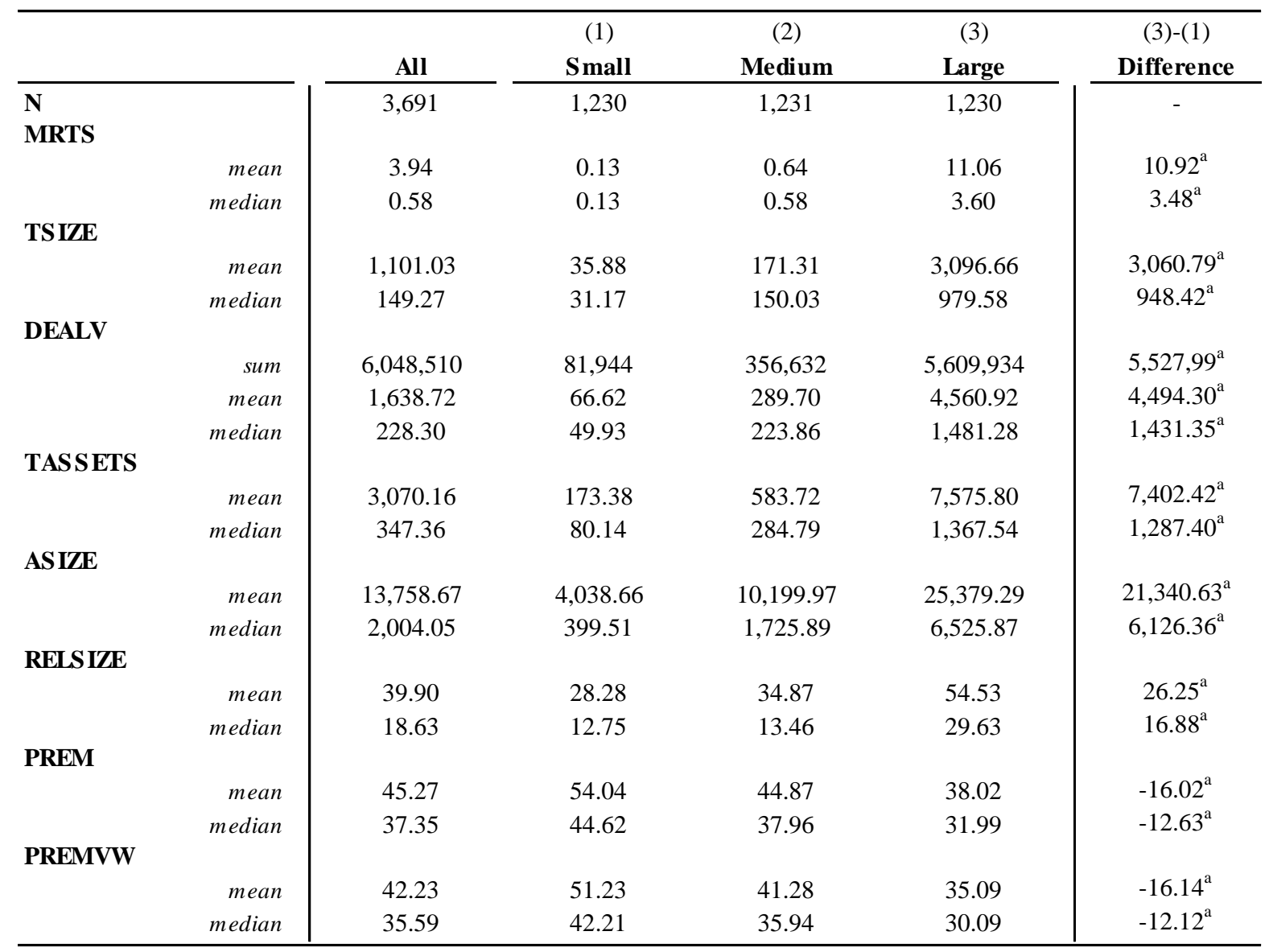


Table III (continued)

\begin{tabular}{|c|c|c|c|c|c|c|}
\hline & & All & $\begin{array}{c}(1) \\
\text { Small } \\
\end{array}$ & $\begin{array}{c}(2) \\
\text { Medium } \\
\end{array}$ & $\begin{array}{c}(3) \\
\text { Large } \\
\end{array}$ & $\begin{array}{c}(3)-(1) \\
\text { Difference } \\
\end{array}$ \\
\hline \multicolumn{7}{|l|}{ PREMR } \\
\hline & mean & $35.38^{\mathrm{a}}$ & $44.67^{\mathrm{a}}$ & $31.89^{\mathrm{a}}$ & $29.50^{\mathrm{a}}$ & $-15.17^{\mathrm{a}}$ \\
\hline & median & $31.50^{\mathrm{a}}$ & $39.39^{\mathrm{a}}$ & $31.00^{\mathrm{a}}$ & $26.56^{\mathrm{a}}$ & $-12.83^{\mathrm{a}}$ \\
\hline \multicolumn{7}{|l|}{ OVERPAY } \\
\hline & mean & -0.26 & $7.24^{\mathrm{a}}$ & -0.80 & $-6.42^{\mathrm{a}}$ & $-13.66^{\mathrm{a}}$ \\
\hline & median & $-4.15^{\mathrm{a}}$ & 0.68 & $-4.66^{\mathrm{a}}$ & $-8.36^{\mathrm{a}}$ & $-9.04^{\mathrm{a}}$ \\
\hline \multicolumn{7}{|l|}{ TCAR3 } \\
\hline & mean & $20.32^{\mathrm{a}}$ & $24.46^{\mathrm{a}}$ & $19.76^{\mathrm{a}}$ & $16.74^{\mathrm{a}}$ & $-7.72^{\mathrm{a}}$ \\
\hline & median & $16.44^{\mathrm{a}}$ & $19.05^{\mathrm{a}}$ & $17.09^{\mathrm{a}}$ & $13.72^{\mathrm{a}}$ & $-5.33^{\mathrm{a}}$ \\
\hline \multicolumn{7}{|l|}{ ACAR3 } \\
\hline & mean & $-1.51^{\mathrm{a}}$ & -0.45 & $-1.08^{\mathrm{a}}$ & $-2.82^{\mathrm{a}}$ & $-2.37^{\mathrm{a}}$ \\
\hline & median & $-1.11^{\mathrm{a}}$ & $-0.58^{\mathrm{a}}$ & $-0.94^{\mathrm{a}}$ & $-2.07^{\mathrm{a}}$ & $-1.49^{\mathrm{a}}$ \\
\hline \multicolumn{7}{|l|}{ ACAR41 } \\
\hline & mean & $-2.44^{\mathrm{a}}$ & 0.33 & $-2.73^{\mathrm{a}}$ & $-4.50^{\mathrm{a}}$ & $-4.83^{\mathrm{a}}$ \\
\hline & median & $-2.25^{\mathrm{a}}$ & 0.15 & $-2.67^{\mathrm{a}}$ & $-3.22^{\mathrm{a}}$ & $-3.37^{\mathrm{a}}$ \\
\hline \multicolumn{7}{|l|}{ COMBI } \\
\hline & mean & $1.11^{\mathrm{a}}$ & $1.82^{\mathrm{a}}$ & $1.05^{\mathrm{a}}$ & $0.55^{\mathrm{a}}$ & $-1.27^{\mathrm{a}}$ \\
\hline & median & $0.66^{\mathrm{a}}$ & $0.92^{\mathrm{a}}$ & $0.62^{\mathrm{a}}$ & $0.39^{\mathrm{b}}$ & $-0.53^{\mathrm{a}}$ \\
\hline \multicolumn{7}{|l|}{ TARGETQ } \\
\hline & mean & 1.84 & 1.40 & 1.66 & 2.37 & $0.97^{\mathrm{a}}$ \\
\hline & median & 1.23 & 1.05 & 1.18 & 1.51 & $0.46^{\mathrm{a}}$ \\
\hline \multicolumn{7}{|l|}{ ACQUIRQ } \\
\hline & mean & 2.35 & 1.95 & 2.14 & 2.88 & $0.93^{\mathrm{a}}$ \\
\hline & median & 1.43 & 1.24 & 1.37 & 1.65 & $0.41^{\mathrm{a}}$ \\
\hline \multicolumn{7}{|l|}{ INS IDE } \\
\hline & mean & 16.63 & 22.79 & 16.75 & 10.88 & $-11.91^{\mathrm{a}}$ \\
\hline & median & 11.30 & 17.20 & 12.45 & 6.61 & $-10.59^{\mathrm{a}}$ \\
\hline \multicolumn{7}{|l|}{ TARAGE } \\
\hline & mean & 10.67 & 8.01 & 9.08 & 14.92 & $6.91^{\mathrm{a}}$ \\
\hline & median & 6.93 & 5.76 & 6.20 & 10.03 & $4.27^{\mathrm{a}}$ \\
\hline \multicolumn{7}{|l|}{ DAYS } \\
\hline & mean & 142.96 & 140.81 & 135.56 & 152.50 & $11.69^{\mathrm{a}}$ \\
\hline & median & 126.00 & 127.00 & 120.00 & 128.00 & 1.00 \\
\hline DIS TRESS & & 25.72 & 37.82 & 22.80 & 18.44 & $-19.38^{\mathrm{a}}$ \\
\hline HUBRIS & & 61.86 & 61.82 & 58.90 & 64.02 & 2.20 \\
\hline COMPETE & & 29.24 & 38.74 & 30.30 & 24.52 & $-14.22^{\mathrm{a}}$ \\
\hline HOS TILE & & 1.30 & 0.57 & 1.14 & 2.21 & $1.64^{\mathrm{a}}$ \\
\hline DIVERS & & 37.44 & 38.94 & 37.45 & 35.93 & -3.01 \\
\hline HIGHVAL & & 38.93 & 36.42 & 41.19 & 39.19 & $2.77^{\mathrm{c}}$ \\
\hline PRIVACQ & & 13.22 & 19.67 & 11.62 & 8.37 & $-11.30^{\mathrm{a}}$ \\
\hline PERCS HARES & & 99.13 & 98.46 & 99.25 & 99.69 & $1.23^{\mathrm{a}}$ \\
\hline ALLCASH & & 31.40 & 41.46 & 32.58 & 20.16 & $-21.03^{\mathrm{a}}$ \\
\hline ALLS TOCK & & 42.08 & 37.07 & 44.60 & 44.55 & $7.48^{\mathrm{a}}$ \\
\hline HYBRID & & 26.52 & 21.46 & 22.82 & 35.28 & $13.82^{\mathrm{a}}$ \\
\hline CASH & & 41.34 & 48.98 & 41.91 & 33.10 & $-15.88^{\mathrm{a}}$ \\
\hline STOCK & & 53.31 & 45.79 & 53.54 & 60.61 & $-14.82^{\mathrm{a}}$ \\
\hline
\end{tabular}


Table IV

\section{Premium Regressions}

The table reports OLS regression estimates of acquisition premium on the natural logarithm of Market-Relative Target Size (LNMRTS) and other deal, firm and market characteristics. The sample includes completed, domestic U.S. mergers and acquisitions of public targets by private and public acquirers, announced between 1990 and 2007 . Deals have transaction value of at least $\$ 1$ million and the acquirer owns less than 10\% of the target shares prior to the announcement and more than $50 \%$ upon completion of the transaction. Target firms are listed on either NYSE, AMEX or

NASDAQ and have data available on CRSP and Compustat. PREM is the ratio of the offer price to the target share price 4 weeks prior to the acquisition announcement for observations between zero and two. PREMVW is the ratio of the offer price to the 30-day $(-45,-15)$ volume-weighted average of the target's trading price, reported for observations between zero and two. PREMR is the cumulative abnormal return to target shareholders calculated over for a 190-day window $(-63,+126)$ around the deal announcement. Target Abnormal Returns (TCAR3) are calculated for a 3-day ($1,+1)$ window around the announcement day. Market-Relative Target Size (MRTS) is measured by the ratio of the market value of the target (in \$million) one month prior to the acquisition announcement and the median market value of all Compustat firms at the announcement year. PRIVACQ is an indicator variable with value of one for acquisitions by unlisted acquiring firms. ACTIVITY is the ratio of the number of listed firms targeted in successful acquisitions within an industry at the announcement year to the number of all firms listed on Compustat within the corresponding target industry and announcement year. HOSTILE, CASH and DIVERS are indicator variables that take the value of one for acquisitions with unsolicited bids, financed $100 \%$ in cash and for transactions where the acquirer and target operate in different industry sectors (2-digit SIC code), respectively. HIVAL is a binary variable equal to one for acquisitions taking place within a high valuation market, based on the de-trended, monthly P/E ratio of the S\&P500 Index. SERIAL takes the value of one for firms that undertake two or more acquisitions within five years. ASIZE is the natural logarithm of the acquirer's market value one month prior to the acquisition announcement. ACQUIRQ and TARGETQ is the market value of assets over the book value of assets for the acquirer and target firm, respectively. INSIDE is the percentage ownership held by all directors and executives of the target firm and their families minus the director ownership representing outside institutions, corporations and individuals. Regressions (4), (8) and (12) control for industry (INDUSTRY FE) and year fixed effects (YEAR FE), the coefficients of which are not reported. pvalues are reported in brackets; $a, b$, and $c$ denote statistical significance at the $1 \%, 5 \%$ and $10 \%$ level. 


\begin{tabular}{|c|c|c|c|c|c|c|c|c|c|c|c|c|c|c|c|c|c|c|c|c|}
\hline & \multicolumn{5}{|c|}{ PREM } & \multicolumn{5}{|c|}{ PREMVW } & \multicolumn{5}{|c|}{ PREMR } & \multicolumn{5}{|c|}{ TCAR3 } \\
\hline & (1) & (2) & (3) & (4) & (5) & (6) & (7) & (8) & (9) & (10) & (11) & (12) & (13) & (14) & (15) & (16) & (17) & (18) & (19) & (20) \\
\hline \multirow[t]{2}{*}{ INTERCEPT } & $0.44^{\mathrm{a}}$ & $0.42^{\mathrm{a}}$ & $0.26^{\mathrm{a}}$ & $0.33^{\mathrm{a}}$ & $0.39^{\mathrm{a}}$ & $0.41^{\mathrm{a}}$ & $0.40^{\mathrm{a}}$ & $0.29^{\mathrm{a}}$ & $0.34^{\mathrm{a}}$ & $0.44^{\mathrm{a}}$ & $0.34^{\mathrm{a}}$ & $0.32^{\mathrm{a}}$ & -0.08 & 0.01 & 0.05 & $0.19^{a}$ & $0.18^{\mathrm{a}}$ & -0.02 & 0.07 & $0.11^{\mathrm{c}}$ \\
\hline & $(0.000)$ & $(0.000)$ & $(0.000)$ & $(0.000)$ & $(0.000)$ & $(0.000)$ & $(0.000)$ & $(0.000)$ & $(0.000)$ & $(0.000)$ & $(0.000)$ & $(0.000)$ & $(0.156)$ & $(0.947)$ & $(0.674)$ & $(0.000)$ & $(0.000)$ & $(0.636)$ & $(0.179)$ & $(0.097)$ \\
\hline \multirow[t]{2}{*}{ LNMRTS } & $-0.040^{a}$ & $-0.053^{a}$ & $-0.065^{\mathrm{a}}$ & $-0.062^{a}$ & $-0.063^{a}$ & $-0.042^{a}$ & $-0.054^{a}$ & $-0.059^{a}$ & $-0.057^{\mathrm{a}}$ & $-0.061^{a}$ & $-0.040^{\mathrm{a}}$ & $-0.047^{a}$ & $-0.090^{a}$ & $-0.073^{a}$ & $-0.059^{a}$ & $-0.021^{a}$ & $-0.021^{a}$ & $-0.045^{\mathrm{a}}$ & $-0.042^{a}$ & $-0.046^{a}$ \\
\hline & $(0.000)$ & $(0.000)$ & $(0.000)$ & $(0.000)$ & $(0.000)$ & $(0.000)$ & $(0.000)$ & $(0.000)$ & $(0.000)$ & $(0.000)$ & $(0.000)$ & $(0.000)$ & $(0.000)$ & $(0.000)$ & $(0.000)$ & $(0.000)$ & $(0.000)$ & $(0.000)$ & $(0.000)$ & $(0.000)$ \\
\hline \multirow[t]{2}{*}{ PRIVACQ } & & $-0.103^{a}$ & & & & & $-0.099^{a}$ & & & & & $-0.167^{a}$ & & & & & $-0.112^{a}$ & & & \\
\hline & & $(0.000)$ & & & & & $(0.000)$ & & & & & $(0.000)$ & & & & & $(0.000)$ & & & \\
\hline \multirow[t]{2}{*}{ ACTIVITY } & & $0.829^{a}$ & $0.808^{a}$ & 0.068 & -0.212 & & $0.734^{\mathrm{a}}$ & $0.747^{\mathrm{a}}$ & 0.095 & -0.239 & & $0.482^{\mathrm{c}}$ & 0.337 & -0.617 & & & 0.100 & 0.030 & -0.042 & -0.046 \\
\hline & & $(0.000)$ & $(0.001)$ & $(0.820)$ & $(0.561)$ & & $(0.000)$ & $(0.000)$ & $(0.733)$ & $(0.477)$ & & $(0.051)$ & $(0.272)$ & $(0.216)$ & $(0.158)$ & & $(0.442)$ & $(0.859)$ & $(0.973)$ & $(0.950)$ \\
\hline \multirow[t]{2}{*}{ HOS TILE } & & $0.209^{a}$ & $0.275^{\mathrm{a}}$ & $0.269^{a}$ & $0.254^{\mathrm{a}}$ & & $0.163^{a}$ & $0.211^{\mathrm{a}}$ & $0.201^{\mathrm{a}}$ & $0.140^{\mathrm{c}}$ & & $0.134^{\mathrm{c}}$ & $0.186^{b}$ & 0.138 & 0.908 & & $0.099^{b}$ & $0.182^{a}$ & $0.168^{\mathrm{a}}$ & 0.061 \\
\hline & & $(0.000)$ & $(0.000)$ & $(0.000)$ & $(0.002)$ & & $(0.001)$ & $(0.001)$ & $(0.001)$ & $(0.070)$ & & $(0.072)$ & $(0.036)$ & $(0.120)$ & $(0.419)$ & & $(0.012)$ & $(0.000)$ & $(0.001)$ & $(0.361)$ \\
\hline \multirow[t]{2}{*}{ CASH } & & $-0.034^{b}$ & $-0.062^{a}$ & $-0.041^{c}$ & -0.035 & & $-0.028^{c}$ & $-0.051^{a}$ & $-0.035^{\mathrm{c}}$ & $-0.038^{c}$ & & $\mathbf{0 . 0 5 3}^{\mathrm{b}}$ & $-0.050^{c}$ & -0.042 & -0.024 & & $0.096^{\mathrm{a}}$ & $0.055^{\mathrm{a}}$ & $0.051^{\mathrm{a}}$ & $0.035^{\mathrm{c}}$ \\
\hline & & $(0.035)$ & $(0.003)$ & $(0.060)$ & $(0.164)$ & & $(0.052)$ & $(0.006)$ & $(0.083)$ & $(0.097)$ & & $(0.014)$ & $(0.070)$ & $(0.137)$ & $(0.484)$ & & $(0.000)$ & $(0.000)$ & $(0.002)$ & $(0.070)$ \\
\hline \multirow[t]{2}{*}{ DIVERS } & & 0.006 & 0.028 & 0.010 & -0.016 & & -0.005 & 0.011 & -0.000 & -0.022 & & 0.002 & 0.024 & 0.011 & -0.001 & & 0.001 & -0.004 & -0.011 & $-0.033^{b}$ \\
\hline & & $(0.703)$ & $(0.110)$ & $(0.591)$ & $(0.469)$ & & $(0.709)$ & $(0.505)$ & (0.989) & $(0.275)$ & & $(0.936)$ & $(0.300)$ & $(0.642)$ & (0.977) & & (0.907) & $(0.752)$ & $(0.400)$ & $(0.049)$ \\
\hline \multirow[t]{2}{*}{ HIVAL } & & & $-0.057^{\mathrm{a}}$ & -0.006 & -0.018 & & & $-0.069^{a}$ & $-0.053^{b}$ & $-0.071^{b}$ & & & $-0.094^{\mathrm{a}}$ & -0.012 & -0.018 & & & $-0.052^{a}$ & -0.026 & $-\mathbf{0 . 0 3 8} 8^{\mathrm{c}}$ \\
\hline & & & $(0.001)$ & $(0.826)$ & $(0.564)$ & & & $(0.001)$ & $(0.035)$ & $(0.012)$ & & & $(0.001)$ & $(0.736)$ & $(0.658)$ & & & $(0.000)$ & $(0.195)$ & $(0.100)$ \\
\hline \multirow[t]{2}{*}{ SERIAL } & & & -0.010 & -0.003 & -0.022 & & & -0.019 & -0.013 & -0.024 & & & $-0.048^{c}$ & $-0.048^{c}$ & $-0.054^{c}$ & & & 0.003 & 0.004 & 0.005 \\
\hline & & & $(0.605)$ & $(0.888)$ & $(0.334)$ & & & $(0.286)$ & $(0.490)$ & $(0.253)$ & & & $(0.057)$ & $(0.058)$ & $(0.075)$ & & & $(0.798)$ & $(0.802)$ & $(0.764)$ \\
\hline \multirow[t]{2}{*}{ AS IZE } & & & $0.020^{\mathrm{a}}$ & $0.021^{\mathrm{a}}$ & $0.023^{\mathrm{a}}$ & & & $0.015^{\mathrm{a}}$ & $0.015^{\mathrm{a}}$ & $0.015^{b}$ & & & $0.060^{a}$ & $0.054^{a}$ & $\mathbf{0 . 0 4 3}^{\mathrm{a}}$ & & & $0.029^{a}$ & $0.029^{a}$ & $0.026^{a}$ \\
\hline & & & $(0.001)$ & $(0.001)$ & $(0.001)$ & & & $(0.008)$ & $(0.010)$ & $(0.021)$ & & & $(0.000)$ & $(0.000)$ & $(0.000)$ & & & $(0.000)$ & $(0.000)$ & $(0.000)$ \\
\hline \multirow[t]{2}{*}{ ACQUIRQ } & & & $0.004^{b}$ & 0.002 & 0.002 & & & $0.007^{\mathrm{a}}$ & $0.005^{\mathrm{a}}$ & 0.003 & & & 0.004 & 0.001 & 0.000 & & & 0.001 & 0.001 & 0.001 \\
\hline & & & $(0.047)$ & $(0.351)$ & $(0.293)$ & & & $(0.000)$ & $(0.007)$ & $(0.168)$ & & & $(0.113)$ & $(0.726)$ & $(0.979)$ & & & $(0.377)$ & $(0.457)$ & $(0.658)$ \\
\hline \multirow[t]{2}{*}{ TARGETQ } & & & $0.007^{\mathrm{c}}$ & 0.002 & 0.003 & & & 0.001 & -0.002 & 0.001 & & & -0.001 & $-0.009^{c}$ & -0.003 & & & -0.002 & -0.002 & 0.000 \\
\hline & & & $(0.075)$ & $(0.559)$ & $(0.403)$ & & & $(0.724)$ & $(0.491)$ & $(0.720)$ & & & $(0.915)$ & $(0.083)$ & $(0.533)$ & & & $(0.491)$ & $(0.434)$ & $(0.870)$ \\
\hline \multirow[t]{2}{*}{ INS IDE } & & & & & 0.028 & & & & & -0.013 & & & & & $0.275^{\mathrm{a}}$ & & & & & 0.066 \\
\hline & & & & & $(0.686)$ & & & & & $(0.844)$ & & & & & $(0.003)$ & & & & & $(0.204)$ \\
\hline INDUS TRY FE & NO & NO & NO & YES & YES & NO & NO & NO & YES & YES & NO & NO & NO & YES & YES & NO & NO & $\mathrm{NO}$ & YES & YES \\
\hline YEAR FE & NO & NO & NO & YES & YES & NO & NO & NO & YES & YES & NO & NO & NO & YES & YES & NO & NO & NO & YES & YES \\
\hline $\mathbf{N}$ & 3,124 & 3,111 & 1,992 & 1,992 & 1,309 & 3,246 & 3,240 & 2,121 & 2,121 & 1,326 & 3,685 & 3,665 & 2,316 & 2,316 & 1,478 & 3,687 & 3,676 & 2,326 & 2,326 & 1,483 \\
\hline R-Square & $4.20 \%$ & $8.30 \%$ & $10.23 \%$ & $17.81 \%$ & $21.81 \%$ & $5.31 \%$ & $9.26 \%$ & $11.22 \%$ & $17.11 \%$ & $21.98 \%$ & $2.32 \%$ & $3.88 \%$ & $8.55 \%$ & $17.06 \%$ & $17.89 \%$ & $2.17 \%$ & $5.73 \%$ & $10.65 \%$ & $14.73 \%$ & $16.23 \%$ \\
\hline
\end{tabular}




\section{Table V \\ Acquirer Return Regressions}

The table reports OLS regression estimates of acquirer abnormal returns (CARs) on the natural logarithm of MarketRelative Target Size (LNMRTS) and other deal, firm and market characteristics. The sample includes completed, domestic U.S. mergers and acquisitions of public targets by private and public acquirers, announced between 1990 and 2007. Deals have transaction value of at least $\$ 1$ million and the acquirer owns less than $10 \%$ of the target shares prior to the announcement and more than 50\% upon completion of the transaction. Target firms are listed on either NYSE, AMEX or NASDAQ and have data available on CRSP and Compustat. Acquirer Abnormal Returns (ACAR3 and ACAR41) are calculated for a 3-day $(-1,+1)$ and a 41-day $(-20,+20)$ event windows around the announcement day, as in Brown and Warner (1985). Market-Relative Target Size (MRTS) is measured by the ratio of the target's market value (in \$million) one month prior to the acquisition announcement and the median market value of all Compustat firms at the announcement year. ACTIVITY is the ratio of the number of listed firms targeted in successful acquisitions within an industry at the announcement year to the number of all firms listed on Compustat within the corresponding target industry and announcement year. HOSTILE, STOCK and DIVERS are indicator variables that take the value of one for acquisitions with unsolicited bids, financed $100 \%$ in stock and for transactions where the acquirer and target operate in different industry sectors (2-digit SIC code), respectively. HIVAL is an indicator variable equal to one for acquisitions taking place within a high valuation market, based on the de-trended, monthly P/E ratio of the S\&P500 Index. SERIAL takes the value of one for firms that undertake two or more acquisitions within five years. ASIZE is the natural logarithm of the acquirer's market value one month prior to the acquisition announcement. ACQUIRQ and TARGETQ is the market value of assets over the book value of assets for the acquirer and target firm, respectively. Regressions (4), (8) and (12) control for industry (INDUSTRY FE) and year fixed effects (YEAR FE), the coefficients of which are not reported. p-values are reported in brackets; a, b, and c denote statistical significance at the $1 \%, 5 \%$ and $10 \%$ level.

\begin{tabular}{|c|c|c|c|c|c|c|c|c|}
\hline & \multicolumn{4}{|c|}{ ACAR3 } & \multicolumn{4}{|c|}{ ACAR41 } \\
\hline & (1) & (2) & (3) & (4) & (5) & (6) & (7) & (8) \\
\hline \multirow[t]{2}{*}{ INTERCEPT } & $-0.02^{a}$ & -0.01 & $-0.03^{a}$ & -0.01 & $-0.03^{a}$ & -0.01 & 0.04 & $0.09^{c}$ \\
\hline & $(0.000)$ & $(0.136)$ & $(0.008)$ & $(0.731)$ & $(0.000)$ & $(0.556)$ & $(0.164)$ & $(0.053)$ \\
\hline \multirow[t]{2}{*}{ LNMRTS } & $-0.007^{a}$ & $-0.007^{a}$ & $-0.008^{a}$ & $-0.010^{a}$ & $-0.013^{a}$ & $-0.014^{a}$ & $-0.010^{a}$ & $-0.009^{\mathrm{a}}$ \\
\hline & $(0.000)$ & $(0.000)$ & $(0.000)$ & $(0.000)$ & $(0.000)$ & $(0.000)$ & $(0.005)$ & $(0.010)$ \\
\hline \multirow[t]{2}{*}{ ACTIVITY } & & -0.014 & -0.038 & -0.065 & & -0.114 & 0.039 & -0.041 \\
\hline & & $(0.799)$ & $(0.507)$ & $(0.379)$ & & $(0.364)$ & $(0.777)$ & $(0.821)$ \\
\hline \multirow[t]{2}{*}{ HOS TILE } & & 0.006 & 0.016 & 0.015 & & 0.022 & 0.043 & 0.039 \\
\hline & & $(0.712)$ & $(0.330)$ & $(0.386)$ & & $(0.564)$ & $(0.285)$ & $(0.338)$ \\
\hline \multirow[t]{2}{*}{ STOCK } & & $-0.026^{a}$ & $-0.021^{a}$ & $-0.018^{a}$ & & $-0.034^{a}$ & $-0.018^{c}$ & -0.012 \\
\hline & & $(0.000)$ & $(0.000)$ & $(0.000)$ & & $(0.000)$ & $(0.083)$ & (0.299) \\
\hline \multirow[t]{2}{*}{ DIVERS } & & 0.006 & 0.004 & -0.000 & & 0.004 & 0.003 & 0.002 \\
\hline & & $(0.113)$ & $(0.389)$ & $(0.985)$ & & $(0.650)$ & $(0.804)$ & $(0.857)$ \\
\hline \multirow[t]{2}{*}{ HIVAL } & & & 0.005 & 0.010 & & & -0.006 & -0.022 \\
\hline & & & $(0.266)$ & $(0.156)$ & & & $(0.552)$ & $(0.188)$ \\
\hline \multirow[t]{2}{*}{ SERIAL } & & & -0.005 & -0.000 & & & -0.005 & 0.002 \\
\hline & & & $(0.246)$ & $(0.938)$ & & & $(0.664)$ & $(0.881)$ \\
\hline \multirow[t]{2}{*}{ AS IZE } & & & $\mathbf{0 . 0 0 3}^{\mathrm{b}}$ & $0.004^{\mathrm{a}}$ & & & -0.004 & -0.006 \\
\hline & & & $(0.028)$ & $(0.001)$ & & & $(0.217)$ & $(0.105)$ \\
\hline \multirow[t]{2}{*}{ ACQUIRQ } & & & $-0.001^{c}$ & -0.000 & & & $-0.009^{a}$ & $-0.009^{a}$ \\
\hline & & & $(0.091)$ & $(0.438)$ & & & $(0.000)$ & $(0.000)$ \\
\hline \multirow[t]{2}{*}{ TARGETQ } & & & -0.000 & 0.001 & & & 0.001 & 0.002 \\
\hline & & & $(0.976)$ & $(0.227)$ & & & $(0.512)$ & $(0.455)$ \\
\hline INDUS TRY FE & NO & NO & NO & YES & NO & NO & NO & YES \\
\hline YEAR FE & NO & NO & NO & YES & NO & NO & NO & YES \\
\hline $\mathbf{N}$ & 3035 & 3031 & 2324 & 2324 & 3020 & 3016 & 2320 & 2320 \\
\hline R-Square & $1,74 \%$ & $3,83 \%$ & $4,14 \%$ & $9,54 \%$ & $1,35 \%$ & $2,05 \%$ & $6,24 \%$ & $9,12 \%$ \\
\hline
\end{tabular}


Table VI

\section{Change in Acquirers' Uncertainty}

The sample includes completed, domestic U.S. mergers and acquisitions of public targets by private and public acquirers, announced between 1990 and 2007. Deals have transaction value of at least $\$ 1$ million and the acquirer owns less than $10 \%$ of the target shares prior to the announcement and more than $50 \%$ upon completion of the transaction. Target firms are listed on either NYSE, AMEX or NASDAQ and have data available on CRSP and Compustat. The sample is split into three groups (Small, Medium and Large) based on MRTS (Market-Relative Target Size) which is measured by the ratio of the market value of the target (in \$million) one month prior to the acquisition announcement and the median market value of all Compustat firms at the announcement year. $\triangle U N C$ is the percentage difference in acquirer's idiosyncratic volatility between the periods $(-200,-20)$ and $(-2,+178)$ relative to the acquisition announcement day, which is measured by the standard deviation of the daily market adjusted residuals. All values are reported in percentages. Differences between the 'Large' and 'Small' subsets are based on two-sample t-tests for means and Wilcoxon-sign rank tests for medians. $a, b$, and c denote statistical significance at the $1 \%, 5 \%$ and $10 \%$ level, respectively.

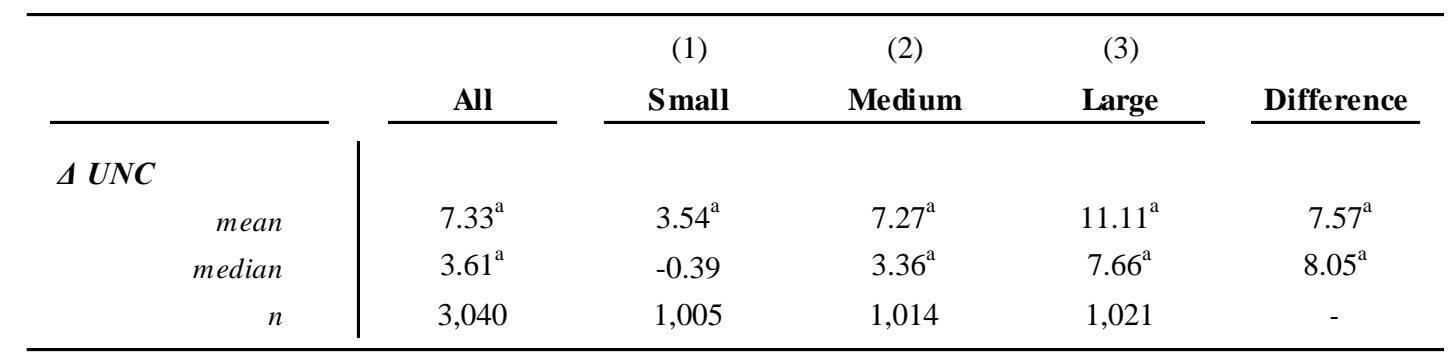


Table VII

\section{Acquisition Premiums and Acquirer Returns by Firm Size}

The sample includes completed, domestic U.S. mergers and acquisitions of public targets by public acquirers, announced between 1990 and 2007. Deals have transaction value of at least \$1 million and the acquirer owns less than $10 \%$ of the target shares prior to the announcement and more than $50 \%$ upon completion of the transaction. Acquirer and target firms are listed on either NYSE, AMEX or NASDAQ and have data available on CRSP and Compustat. The sample is split into mutually exclusive groups (Small, Medium and Large) based on MarketRelative Target Size (MRTS) and Market-Relative Acquirer Size (MRAS), measured as target and acquirer market value, respectively, one month prior to the acquisition announcement over the median market value of all Compustat firms at the announcement year. PREM is the ratio of the offer price to the target share price 4 weeks prior to the acquisition announcement for observations between zero and two. ACAR3 is the cumulative abnormal return calculated for a 3-day $(-1,+1)$ event window around the announcement day, as in Brown and Warner (1985). All values are reported in percentages. Differences between the 'Large' and 'Small' subsets are based on twosample t-tests for means and Wilcoxon-sign rank tests for medians. $a, b$, and c denote statistical significance at the $1 \%, 5 \%$ and $10 \%$ level, respectively.

MRTS

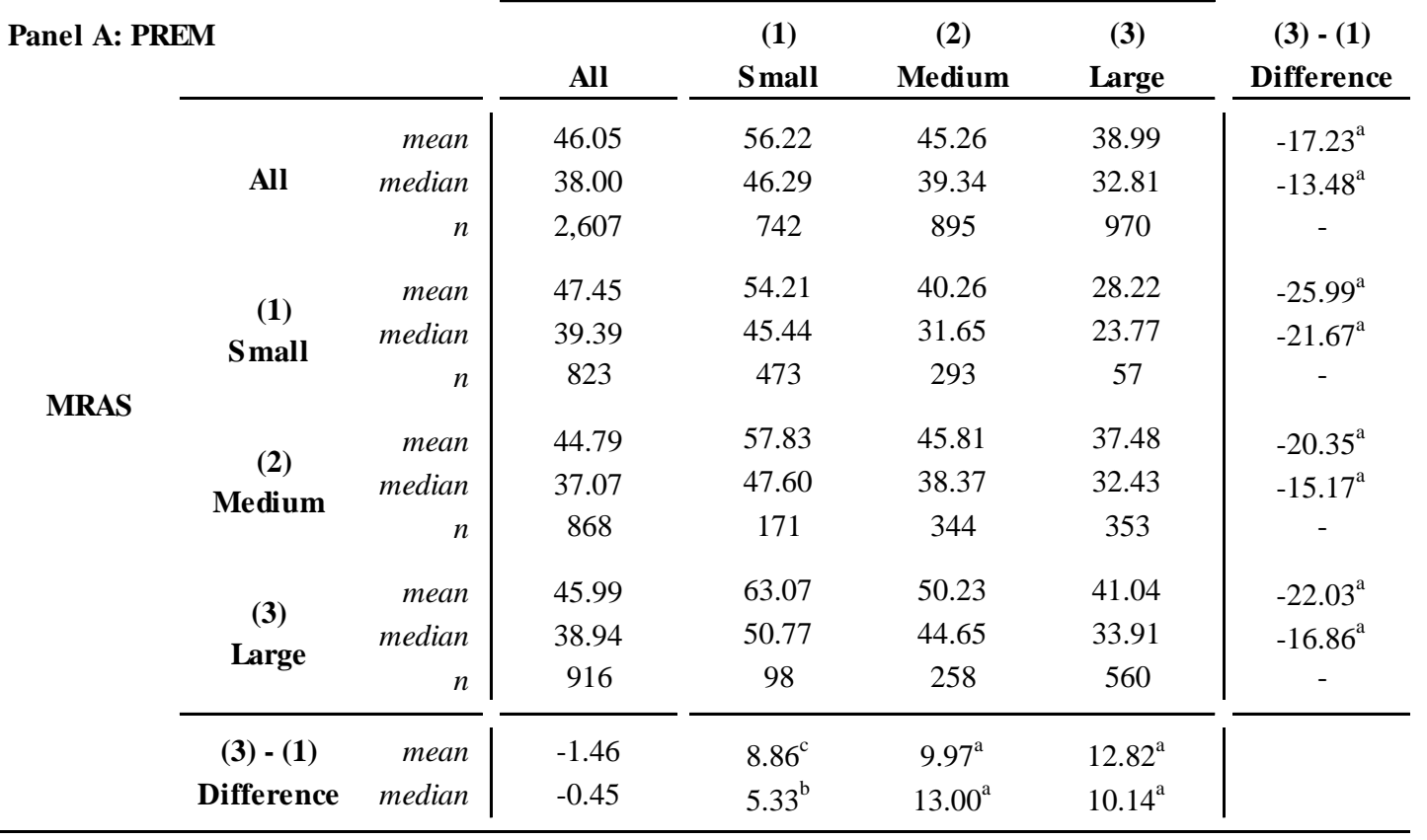

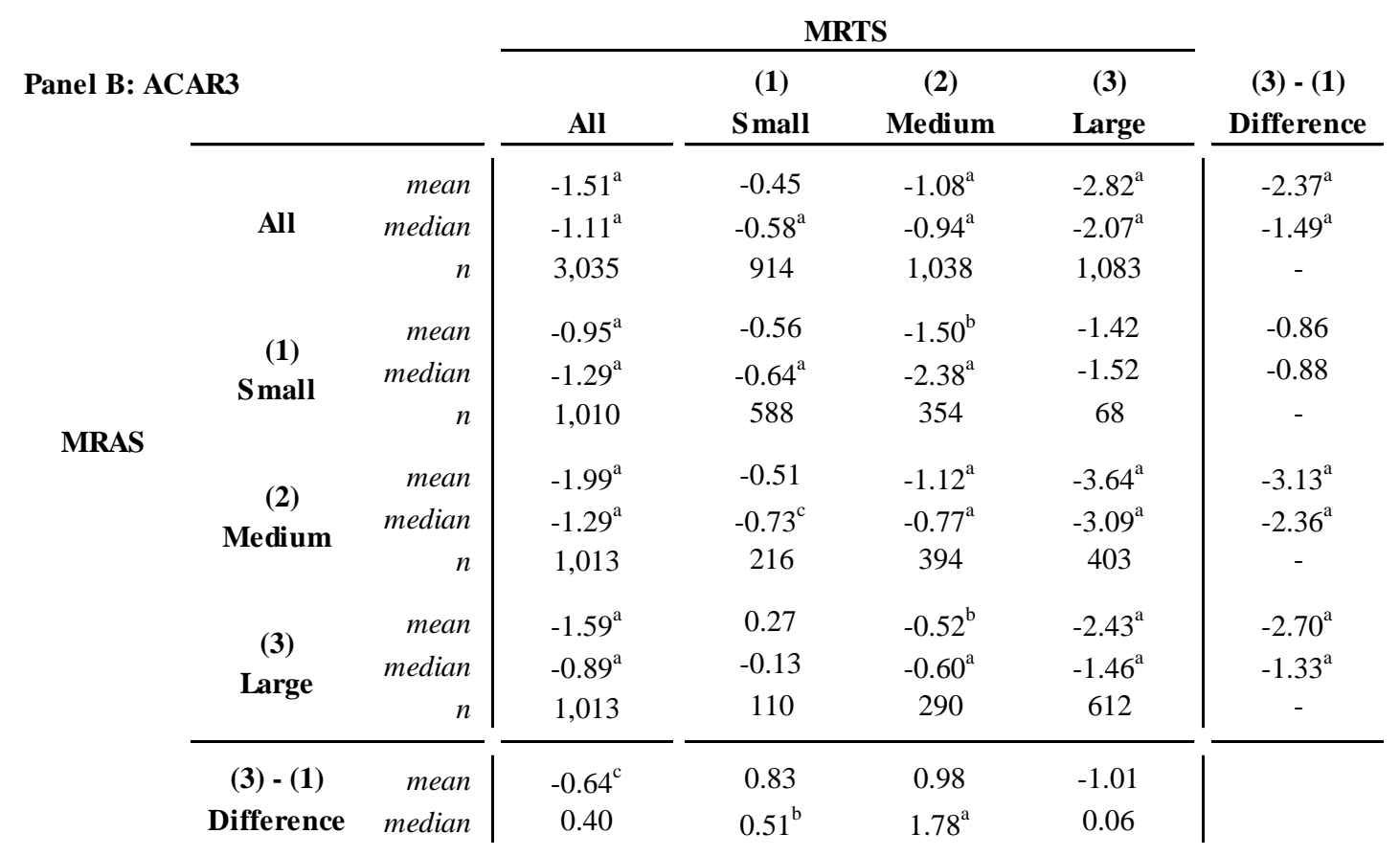




\section{Table VIII}

\section{Acquirer Long-Run Performance - Calendar-Time Portfolio Regressions}

The table reports monthly percentage estimates (alphas) of acquirer abnormal returns from Calendar Time Portfolio Regressions. Acquirers enter the portfolio on the completion month of each transaction and remain for 12 or 36 months. At least ten firms per calendar month and target size subgroup are required to calculate the monthly portfolio return. The monthly acquirer abnormal return is calculated using a time-series regression of the following form: $\quad R_{p t}-R_{f t}=\alpha_{p}+\beta_{p}\left(R_{M t}-R_{f t}\right)+s_{p} S M B_{t}+h_{p} H M L_{t}+u_{p} U M D_{t}+\varepsilon_{p t}$, where the dependent variable, $R_{p t}-R_{f t}$, is the equally-weighted, monthly calendar time portfolio excess return. The independent variables are the Fama/French (1993) and Carhart (1997) factors. The sample is split into three groups (Small, Medium and Large) based on MRTS (Market-Relative Target Size) which is measured by the ratio of the market value of the target (in \$million) one month prior to the acquisition announcement and the median market value of all Compustat firms at the announcement year. All values are reported in percentages. 'Large' minus 'Small' difference estimates are from zero investment portfolio regressions. a, b, and c denote statistical significance at the $1 \%, 5 \%$ and $10 \%$ level.

\begin{tabular}{|c|c|c|c|c|c|}
\hline & \multirow[b]{2}{*}{ All } & \multicolumn{3}{|c|}{ 12months CTPR } & \multirow[b]{2}{*}{$\begin{array}{c}(3)-(1) \\
\text { Difference }\end{array}$} \\
\hline & & $\begin{array}{c}(1) \\
\text { Small } \\
\end{array}$ & $\begin{array}{c}(2) \\
\text { Medium }\end{array}$ & $\begin{array}{c}(3) \\
\text { Large }\end{array}$ & \\
\hline CTPR alpha & -0.051 & 0.220 & 0.100 & $-0.283^{\mathrm{b}}$ & $-0.489^{b}$ \\
\hline p-value & $(0.675)$ & $(0.248)$ & $(0.588)$ & $(0.047)$ & $(0.030)$ \\
\hline $\mathbf{n}$ & 3,016 & 1,003 & 1,007 & 1,006 & - \\
\hline Calendar Months & 221 & 216 & 215 & 215 & 214 \\
\hline \multirow[t]{4}{*}{ R-Square } & $90.42 \%$ & $78.03 \%$ & $78.67 \%$ & $88.41 \%$ & $35.11 \%$ \\
\hline & & \multicolumn{3}{|c|}{ 36months CTPR } & \\
\hline & & (1) & (2) & (3) & (3)-(1) \\
\hline & All & Small & Medium & Large & Difference \\
\hline CTPR alpha & -0.054 & $0.240^{\mathrm{c}}$ & 0.104 & $-0.195^{\mathrm{c}}$ & $-0.443^{\mathrm{a}}$ \\
\hline p-value & $(0.594)$ & $(0.100)$ & $(0.431)$ & $(0.078)$ & $(0.006)$ \\
\hline $\mathbf{n}$ & 3,016 & 1,003 & 1,007 & 1,006 & - \\
\hline Calendar Months & 221 & 218 & 216 & 217 & 217 \\
\hline R-Square & $92.49 \%$ & $84.00 \%$ & $87.60 \%$ & $91.63 \%$ & $45.13 \%$ \\
\hline
\end{tabular}


Table IX

Pre- and Post-Acquisition Operating Performance

The table reports median annual operating performance before and after the year of the acquisition announcement. Return on Assets is the ratio of operating income to total assets. Industry-Adjusted Return on Assets is the difference between the operating performance of the sample firm and the median return on assets of the corresponding industry. Pre-Merger Returns on Assets are pro forma returns for the combined firm, calculated as weighted averages of target and acquirer returns where the weights are the relative assets values of the acquirer and target firm. Post-Merger Returns on Assets are based on data for the new entity. Industry returns prior to the acquisition are weighted averages of the median industry return for the respective acquirer and target industries, where the weights are the relative asset values of the acquirer and target firms for each year. Industry returns subsequent to the year of the acquisition announcement are calculated with the relative asset weights of the acquiring and target firms from Year -1. The sample is split into three groups (Small, Medium and Large) based on MRTS (Market-Relative Target Size) which is measured by the ratio of the market value of the target (in \$million) one month prior to the acquisition announcement and the median market value of all Compustat firms at the announcement year. All values are reported in percentages. Differences between the pre-merger and postmerger three-year median (industry-adjusted) return on assets are based on the Wilcoxon-sign-rank tests for medians. a, $\mathrm{b}$, and c denote statistical significance at the $1 \%, 5 \%$ and $10 \%$ level, respectively.

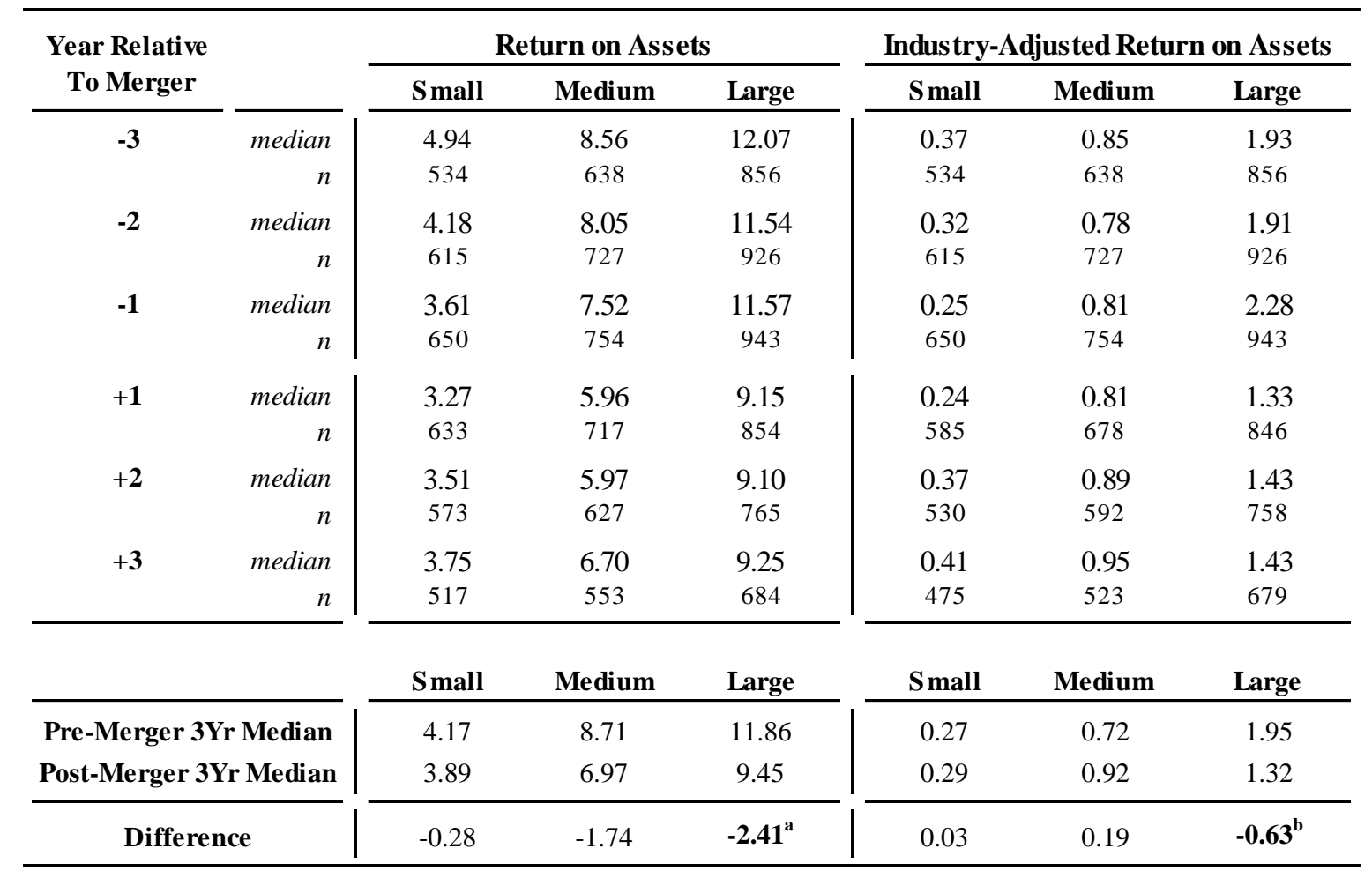




\section{Figure I}

\section{Acquisition Premium over Time: Small vs. Large Targets}

The sample includes completed, domestic U.S. mergers and acquisitions of public targets by private and public acquirers, announced between 1990 and 2007. Deals have transaction value of at least \$1 million and the acquirer owns less than $10 \%$ of the target shares prior to the announcement and more than $50 \%$ upon completion of the transaction. Target firms are listed on either NYSE, AMEX or NASDAQ and have data available on CRSP and Compustat. The sample is split into three groups (Small, Medium and Large) based on MRTS (Market-Relative Target Size) which is the ratio of the market value of the target (in \$million) one month prior to the acquisition announcement and the median market value of all Compustat firms at the announcement year. PREM is the ratio of the offer price to the target share price 4 weeks prior to the acquisition announcement for observations between zero and two. PREMR is the cumulative abnormal return to target shareholders calculated over for a 190-day $(-63,+126)$ window around the deal announcement. PREMVW is the ratio of the offer price to the 30-day $(-45,-15)$ volume-weighted average of the target's trading price, reported for observations between zero and two.
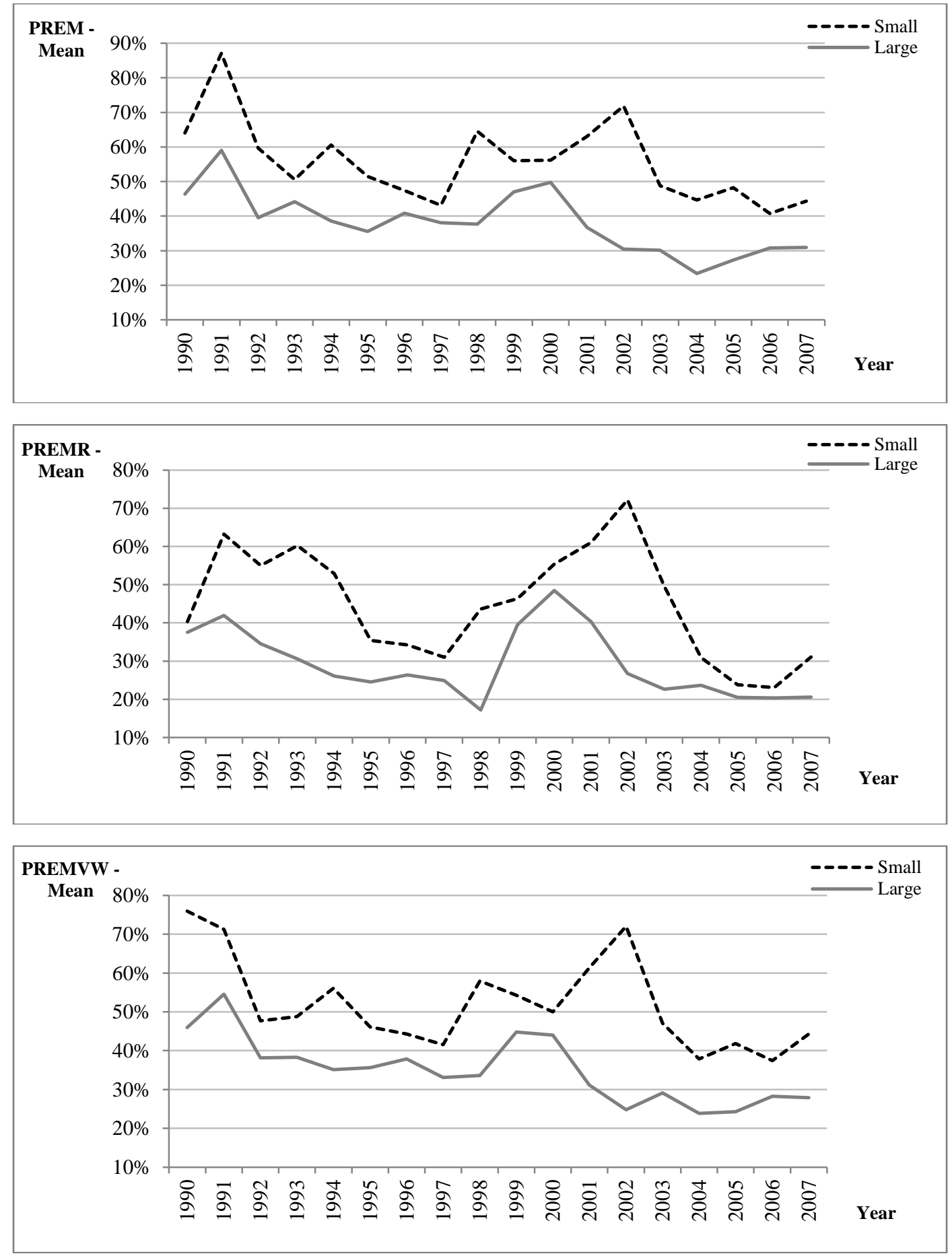